\title{
LEGAL DOCTRINES GOVERNING THE ADMISSIBILITY OF EXPERT TESTIMONY CONCERNING SOCIAL FRAMEWORK EVIDENCE
}

\author{
Robert P. Mosteller*
}

\section{INTRODUCTION}

Professors Walker and Monahan have coined the term "framework evidence" to describe "the use of general conclusions from social science research in determining factual issues in a specific case." In this article, I examine the legal doctrines that govern the admissibility of social framework testimony. My general purpose is to highlight the social science assumptions undergirding the applicable evidentiary principles and to suggest some potentially fruitful areas for further empirical research.

I focus principally on the admission of social framework evidence in two types of cases: sexual abuse of children and rape involving adult female victims. $^{2}$ I analyze the issue under the assumption that the jury is the factfinder. ${ }^{3}$

In this article, I construe the concept of social framework evidence relatively broadly. ${ }^{4}$ My premise is that testimony that relies on a comparison

Copyright $(\mathcal{C} 1989$ by Law and Contemporary Problems

* Senior Associate Dean for Academic Affairs and Professor of Law, Duke University.

I would like to thank David Kaye, Toni Massaro, and Neil Vidmar for their valuable comments on an earlier draft of this article and Michael Carroll for his assistance with the research.

1. Walker \& Monahan, Social Frameworks: A New Use of Social Science in Law, 73 VA. L. Rev. 559, 570 (1987) (emphasis removed) (footnote omitted) [hereinafter Walker \& Monahan]. See also Walker \& Monăhan, Social Facts: Scientific Methodology as Legal Precedent, 76 CALIf. L. Rev. 877 (1988) [hereinafter Walker \& Monahan, Scientific Methodology as Precedent]; Walker \& Monahan, Social Authority: Obtaining. Evaluating, and Establishing Social Science in Law. 134 U. PA. L. Rev. 477 (1986).

2. Because some of the most sophisticated empirical research has been conducted in the area of eyewitness identification, I will on occasion use that research to analyze some issues.

3. Because of the widespread assumption that the problem of overvaluation of scientific and technical evidence is chiefly a problem that affects lay factfinders, I assume throughout this article that the jury is the factinder. It should not necessarily be assumed, however, that judges are immune to the effects of myths and misconceptions, particularly in the highly charged areas of rape and child sexual abuse. See Massaro, Experts, Psychology, Credibility, and Rape: The Rape Trauma Syndrome Issue and Its Implications for Expert Psychological Testimony, 69 MinN. L. Rev. 395, 468 (1985) (arguing that myths and fears concerning rape may influence judicial decisions not to admit expert evidence concerning the rape (rauma syndrome).

4. My construction of social framework evidence is broader than that used by Walker and Monahan. For a more complete discussion of the differences between my construction of social framework evidence and that of Monahan and Walker and my reasons for a broader construction of framework evidence, see infra Part III. 
between a participant in the litigation and a larger social grouping possesses the core element of social framework testimony, regardless of whether the expert testifies to an explicit framework based on the behavior and characteristics of a group. ${ }^{5}$

As a lawyer, I come to the issues raised in this symposium with a somewhat different perspective from most of the other participants whose training is in the social sciences. I am generally familiar and largely comfortable with the arcane and scientifically suspect legal classifications by which admissibility is judged. Nevertheless, even lawyers who examine the operation of the legal doctrines in this area may rightfully react with some despair. ${ }^{6}$

The reasons for despair are numerous. First, the doctrines are a jumble. Although they often rest on some of the concerns that properly should guide admissibility, these doctrines consist of a series of antiquated tests with their origins in the common law; they cut one way and then another across the field. They are defended on the ground that they frequently produce rational, appropriate results. ${ }^{7}$ Admissibility analysis that abandons the common law doctrines and directly focuses on the core concepts appears, however, to be a better solution.

Second, neither legal scholars nor social scientists are making significant progress in resolving the problems in this area. Professor Tribe wrote in 1971 about the difficulties, which he believed were insuperable, of combining statistical and probabilistic evidence with other types of proof. ${ }^{8}$ Many of the issues he identified, and much of the terminology he employed, still dominate analysis of social framework evidence both in the courts and in legal scholarship. This is true in spite of substantial research that suggests the

5. My position in this article is that the evidence should be considered under the social framework rubric even if it is based on a series of clinical observations rather than on systematic analysis of a substantial data base. See Saks \& Kidd, Human Information Processing and Adjudicalion: Trial by Heuristics, 15 LAw \& Soc'y REv. 123, $151-54$ (1981) (arguing that apparently case-specific information is only superficially distinct from probabilistic base-rate information). See also Tribe, Trial by Mathematics: Precision and Ritual in the Legal Process, 84 HARv. L. Rev. 1329, 1330 n.2, $1360-61$ (1971) (acknowledging the fundamental kinship between probabilistic evidence and apparently specific testimony, but contending that explicitly probabilistic evidence has a vastly greater impact on the jury because, inter alia, hard numbers dwarf the impact of evidence that is not quantified). In contrast to Professor Tribe, others suggest that methods of presentation other than the use of statistics-for example, direct linkage of the social phenomenon to the individual case or a direct opinion regarding witness credibility-may be as powerful, or perhaps even more powerful, than a statistical presentation of framework evidence. See infra note 58.

6. See McCord, Expert Psychological Testimony about Child Complainants in Sexual Abuse Prosecutions: A Foray into the Admissibility of Novel Psychological Evidence, 77 J. Crim. L. \& Criminology 1, 24-26 (1986) (describing the "unsatisfactory state of the case law" with regard to admissibility analysis); Myers et al., Expert Testimony in Child Sexual Abuse Litigation, 68 NeB. L. Rev. 1, 5 (1989) (noting that few lawyers or judges can understand the expanding non-legal literature on child sexual abuse and recommending an interdisciplinary approach).

7. For example, Professor Lempert argues that the "general acceptance" test of Frye v. United States, 293 F. 1013, 1014 (D.C. Cir. 1923), has a basically sound justification: "If psychologists cannot arrive at a consensus on the value of [psychological] testimony, how can a psychologically naive judge, whose primary task is to resolve the case in front of him, be expected to value it properly?" Lempert, Social Science in Court: On "Eyewitness Experts" and Other Issues, 10 LAW \& Hum. BEHAV. 167, 175 (1986).

8. Tribe, supra note 5. 
invalidity of Tribe's underlying factual premise that lay jurors would be overwhelmed by statistical evidence. ${ }^{9}$

Third, empirical research is proving of relatively little immediate help to the courts in making the decision on admissibility. A number of issues play an important role here, and many of them depend upon factual assumptions that are subject to empirical examination. Among these issues are:

- How reliable is the research concerning the child sexual abuse and rape trauma syndromes? ${ }^{10}$

- How misguided are contemporary public perceptions concerning the typical reactions of a sexually abused child and an adult rape victim? ${ }^{\prime \prime}$

- Is a jury likely to attach relatively too much weight to expert testimony concerning the social framework characteristics of these two victim groups?

- How does the impact of the expert testimony differ depending upon whether general research findings are presented or whether a clinical evaluation of the particular alleged victim is given?

- What are the characteristics of expert testimony that make it particularly susceptible to misuse and overvaluation by a jury (scientific jargon, statistical evidence, use of apparently sophisticated hardware, direct testimony by expert about the witness' credibility)? Are the characteristics that lead to overvaluation of testimony easily generalized from one subject matter area to another? 12

- How accessible is social science research in these areas to judicial decisionmakers when they attempt to determine the reliability of scientific evidence and the impact it is likely to have on jurors? 13

- What is the relative value of social framework evidence, weighing the benefit of correcting juror ignorance of a social phenomenon against the likely inappropriate impact of the testimony upon the jurors? Does social science research have any substantial chance of answering this final question in the near term?

9. See Vidmar, Assessing the Impact of Statistical Evidence, A Social Science Perspective, in THE Evolving Role of Statistical Assessments as Evidence in the Courts 297 (S. Fienberg ed. 1988) [hereinafter Evolving Role] ("The main conclusion that the authors of almost all of these studies draw is that jurors do not give undue weight or credibility to expert evidence."); Walker \& Monahan, supra note 1, at 576 ("It appears that aggregate 'statistical' information, in actual practice, is likely to be highly undervalued by lay decisionmakers.").

Moreover, lawyers and judges, while purporting to use social science concepts, tend both to use primitive ideas-often, in fact, erroneous analyses-and to approach the use of such evidence and the resources offered by the social sciences with considerable skepticism. Gold, Jury Wobble: Judicial Tolerance of Jury Inferential Error, 59 S. CAL. L. REv. 391, 395, 399, $402-03$ (1986). See also infra note 100. Moreover, the prospect for rapid change is not bright, since the interaction of factors occurring in litigation is extraordinarily complex and it is likely to be some time before they may be fully and accurately analyzed.

10. See infra notes 106-07, 165, 174 and accompanying text.

11. See infra notes $104-05,118,165,174$ and accompanying text.

12. See infra note 65 .

13. See infra note 100 . 
On some of these issues, researchers have made substantial progress, but resolution does not appear near at hand for many of them. Probably more importantly, we may never be able to resolve these issues when they are posed simultaneously, as generally occurs in the context of actual litigation.

Fourth, what may be termed bias has a disproportionately large impact upon the outcome of legal analysis concerning the admissibility of social framework testimony. Courts and lawyers schooled in the craft of lawyering but not in the social sciences seem all too ready to develop arguments against using new learning. Similarly, social scientists have their own biases and feelings about the legal profession's treatment of their field. ${ }^{14}$ In much the same way that lawyers tend to react negatively to the introduction of new learning in the courts, social scientists appear too ready to give assurance that the new learning will have only beneficial effects and can be integrated into the trial process without harm to the process. ${ }^{15}$

Another important source of bias is the operation of a strong result orientation that appears to play a major role in determining the admissibility of social framework evidence. Many types of social framework testimony have a predictable impact of favoring one side in a particular type of litigation. As a result, courts making the admissibility decision for a class of testimony may be swayed by their feelings about what they perceive to be the correct result of the litigation.

For instance, the criminal defendant is almost always the party who seeks to admit expert testimony concerning eyewitness identification, apparently because such testimony is perceived as increasing the prospects for acquittal in most cases where identification testimony constitutes a significant element of the state's case. ${ }^{16}$ This perception has at least arguable scientific merit,

14. There is certainly an air of mutual hostility in some of the writings of lawyers and psychologists concerning each other's role in the legal process and the accurate adjudication of factual issues. McCord, Syndromes, Profiles and Other Mental Exotica: A New Approach to the Admissibility of Nontraditional Psychological Evidence in Criminal Cases, 66 OR. L. REv. 19, 21-23 (1987).

15. It would not be fair to say that all social scientists take the view that admission of their expertise will only benefit the trial process. Notably, Professors McCloskey and Egeth argue that, in the eyewitness area, it is far from clear that testimony by psychologists concerning the problems of eyewitness identification would improve the ability of jurors to evaluate such identification evidence. Expert testimony, they argue, may in fact have detrimental effects on the process. McCloskey \& Egeth, Eyewitness Identification: What Can a Psychologist Tell a Jury?, 38 Aм. Psychologist 550 (1983); McCloskey \& Egeth, A Time to Speak, or a Time to Keep Silent, 38 Aм. Psychologist 573 (1983). See also McCloskey, Egeth \& McKenna, The Experimental Psychologist in Court: The Ethics of Expert Testimony, 10 LAW \& HuM. BeHAV. I (1986).

16. Professor Lempert has argued that justice, defined in terms of the probability of accurate jury verdicts, will be enhanced if expert testimony in eyewitness identification cases is admitted when the evidence of guilt, apart from the eyewitness identification testimony, is weak, and excluded when the other evidence in the case is strong. Lempert, supra note 7 , at 170-71. Where the eyewitness testimony is consistent with a substantial body of other evidence pointing to guilt, he argues that, in a probabilistic sense, the eyewitness testimony is likely to be accurate. Moreover, in such circumstances, he believes, the tendency to overvalue eyewitness testimony is corrected by a natural tendency to undervalue the cumulative impact of circumstantial evidence. Id. at 170 .

The admission of eyewitness evidence only when the other evidence of guilt is weak could be justified because of the likelihood that defense counsel will attempt to overemphasize the significance of such expert eyewitness testimony. Where the evidence independent of the eyewitness testimony is strong, the defense may be able artificially to focus the jury's attention on the weakness 
since some research indicates that expert testimony does not help mock jurors distinguish between accurate and inaccurate eyewitness testimony. Instead, a major impact of the testimony is to increase the tendency of jurors to disbelieve eyewitness testimony, with the result that mock jurors may give it less weight than the empirical results indicate it warrants. ${ }^{17}$

of the eyewitness testimony by attacking that testimony with the support of expert testimony. If effectively presented, that attack may diminish the impact of the other evidence by reducing its apparent significance, producing an erroneous result. Where the other evidence of guilt is weak, however, there can be little danger of overattention to the weakness of the eyewitness testimony.

Professor Lempert's suggestion usefully explains when some types of framework evidence should be admissible, but the explanation appears limited to evidence assisting the defendant, as expert testimony about eyewitness identification generally does. His major argument, which rests upon a probability assessment, also has a strong due process-type justification and is not derived principally from evidentiary concerns embodied in the relevancy and helpfulness concepts developed below. See infra Parts II.B, C.

Where the evidence of the defendant's guilt apart from the eyewitness testimony is weak, due process, in the sense of fundamental fairness, supports admission of evidence that assists the defense in attacking eyewitness testimony. The argument is much like that under which reliable hearsay was admitted in Chambers v. Mississippi, 410 U.S. 284, 302 (1973). Courts have admitted other evidence, such as the psychiatric examination of an alleged rape victim in Ballard v. Superior Court, 64 Cal. 2d 159, 176-77, 410 P.2d 838, 849, 49 Cal. Rptr. 302, 313 (1966), under similar arguments. The courts in these situations appropriately "peek at the merits" in ways that they are typically not overtly permitted to do, given the dangers that accompany an explicitly result-oriented jurisprudence.

When the framework evidence is to be admitted against rather than in favor of the defendant, Professor's Lempert's analysis does not appear to apply. And while courts may use a "necessity" argument in both situations, as the court did in Ballard, id., to support admission, the meaning of the term differs according to whether the evidence supports or harms the defense.

The example of framework testimony supporting the credibility of a child witness in a sexual abuse case illustrates the differences between the two cases. First, if the evidence of guilt, independent of the testimony of the witness affected by the framework evidence, is weak, Professor Lempert's probabilistic argument suggests that the child's testimony is likely to be inaccurate and therefore, if admitted, the framework evidence would be used in support of an erroneous outcome. This result is the reverse of that in the eyewitness situation and suggests that the evidence should be excluded. Second, in the child sexual abuse case, necessity in a due-process sense-the sense of avoiding a fundamentally unfair outcome-does not operate, since the state has no due-process protection. Third, in the child sexual abuse case, necessity may exist for the evidence in the sense that there are no alternative ways to establish the same point or reach the same result. In contrast, in the eyewitness case suggested above, this type of necessity is almost entirely lacking. Given the weak case for the state, testimony concerning eyewitness fallibility may be entirely unnecessary and the state's case may be subjected to effective attack in alternative ways precisely because it is otherwise weak.

Moreover, the argument that supports admissibility of framework testimony in both eyewitness and child sexual abuse cases has generally limited importance in determining admissibility under standard evidentiary analysis. Because of the otherwise weak case for the state, the credibility of the particular witness whose testimony would be affected by the framework evidence will be considered of sufficient importance to justify the expenditure of considerable time and some substantial confusion of issues to attack or support it. However, neither consumption of time nor confusion of issues tends to be high in the hierarchy of concerns that typically lead courts to exclude framework evidence. Also, the fact that credibility is important does not mean that the danger of juror overvaluation of the expert's testimony will be reduced. Indeed, such danger may be greater in these circumstances, and it is the danger of overvaluing the evidence that causes the most concern to courts about the use of such evidence.

17. Sanders, Expert Witness in Eyewitness Facial Identification Cases, 17 Tex. Tech L. Rev. 1409, 1459-64 (1986).

Professor Sanders observes that the scientific community makes little note of the fact that it is producing evidence in the eyewitness area that tends to help only one side. Id. at 1460 . He believes, however, that this issue lurks near the surface of the debate on admissibility. Id. at 1468. Others. including Professors Penrod and Cutler in their article in this issue, disagree with Sanders' basic 
In child sexual abuse cases, the prosecution is the party that benefits from the evidence. Currently, child sexual abuse is correctly seen as a major social problem. As a result of the public perception, social scientists and the courts are eager to join forces in attacking the problem. I suggest that in this area, as in eyewitness identification, social framework testimony relevant to the credibility of an alleged child victim, for example, does not enable the jurors

premise and argue that the effect of expert testimony is not to produce skepticism. Penrod \& Cutler, Eyewitness Expert Testimony and Jury Decisionmaking, Law \& ConTemp. Probs., Autumn 1989, at 43. See also Cutler, Penrod \& Drexler, The Eyewitness, the Expert Psychologist, and the Jury, 13 Law \& Hum. Behav. 311, 324-26 (1989) (results in mock trial showed expert testimony regarding eyewitness identification increased juror sensitivity to witnessing conditions but did not increase skepticism).

In resolving the issue of whether skepticism is produced, one must confront a definitional difficulty. Does testimony produce "skepticism" if it causes jurors to reduce the value given to eyewitness testimony across the board when that testimony was initially overvalued, or is that reduction an appropriate adjustment if it takes account of other factors pertaining to the conditions under which the identification is made? This difficult question might be avoided if expert testimony effectively helped jurors distinguish witnesses who correctly picked the perpetrator from those who made an incorrect selection when the two sets of witnesses viewed the crime under identical conditions. Given the ability of researchers to conduct controlled experiments where the true perpetrator is known, it is possible to test that possibility. The results appear to be conflicting. Compare Wells, Lindsay \& Tousignant, Effects of Expert Psychological Advice on Human Performance in Judging Validity of Eyewitness Testimony, 4 LAW \& HUM. BeHAV. 275, 282-83 (1980) (effect of expert testimony was to reduce mock jurors' belief that witnesses made accurate identification, and the testimony had no statistically significant effects on the ability of the jurors either to tell accurate from inaccurate witnesses or to take better account of conditions of observations), with Wells, Expert Psychological Testimony: Empirical and Conceptual Analyses of Effects, 10 LAW \& Hum. Benav. 83, 86-88 (1986) (recounting statistically significant results of study by Wells and Wright in which expert testimony both permitted mock jurors to distinguish between accurate and inaccurate witnesses and to take witnessing conditions into account).

While some expert testimony concerning eyewitness identification may aid in distinguishing between accurate and inaccurate witnesses, it is relatively difficult to imagine how much of that testimony could aid in discrimination when all witnesses are sincere in their beliefs and viewed the crime under identical conditions. The expert testimony may aid discrimination where, for example, one witness is of the same race as the suspect while another must make a more difficult cross-racial identification. See Brigham \& Malpass, The Role of Experience and Contact in the Recognition of Faces of Own- and Other-Race Persons, $12 \mathrm{~J}$. Soc. Issues 139, 142-44 (1985) (finding consistent results that both black and white subjects tend to recognize faces of their own race better than those of the other race); but see Lindsay \& Wells, What Do We Really Know About Cross-Race Eyewitness Identification?, in Evaluating Witness Evidence 219 (S. Lloyd \& B. Clifford eds. 1983) (empirical results on crossracial identification are inconsistent and research lacks effective explanatory theories). Also, discrimination between accurate and inaccurate witnesses may be enhanced by psychological testimony where one witness provides substantial information concerning peripheral detail in the observation setting, which prospective jurors are likely to believe erroneously correlates positively with an accurate identification. Wells \& Leippe, How Do Triers of Fact Infer the Accuracy of Eyewitness Identifications? Using Memory for Peripheral Detail Can Be Misleading, 66 J. Applied Psychology 682, 686 (1981). As to other factors, such as the length of observation when it is the same for both accurate and inaccurate witnesses, the expert should not be able to offer help in making accurate discriminations.

As a result, the most significant impact of expert testimony is to reduce acceptance of eyewitness testimony generally, regardless of whether the witness' identification of the defendant is in fact accurate. This impact may be appropriate if that reduction has the effect of lowering the acceptance of such testimony from an improperly high point to a level commensurate with the predicted accuracy under the witnessing conditions.

However, as discussed infra, see text at notes 19-20, in this limited beneficial effect lies the rub. The propriety of admitting expert testimony on eyewitness testimony depends on a delicate balance between the level of current jury overvaluation of eyewitness testimony and the jury's ability to receive expert testimony that corrects such misperception without producing overvaluing of the expert testimony itself. See infra note 21 and accompanying text. 
to determine whether an individual is telling the truth in that it does not generally give the jury guidance on how to decide whether a particular child is telling the truth. Rather, the framework testimony tells jurors only that children who make such allegations are generally highly credible. The result of admitting framework evidence on credibility is accordingly to tilt the likely outcome in a predictable direction to disfavor the criminal defendant. ${ }^{18}$

Finally, social framework testimony of the type that will be examined in this article appears to be clearly helpful in reaching accurate decisions, but it has characteristics that make its salutary use relatively fragile, that subject it to relatively easy misuse, and that render blanket decisions about the propriety of admissibility problematic. Those characteristics are related, first, to the point discussed above about the predictable direction of impact of the evidence and, second, to the somewhat limited utility of the evidence.

With regard to the first point, social framework evidence has a predictable impact because of what we know about general juror reactions in the absence of the framework evidence. In the area of eyewitness identification evidence, for example, many researchers find that jurors have a tendency to overbelieve the testimony of an eyewitness and to be insensitive to the conditions under which the observations that led to the the identification occurred. ${ }^{19}$ Expert testimony, many of these researchers argue, has a proper impact when it makes jurors appropriately skeptical of eyewitness identification in the sense that they evaluate it according to its likely accuracy. ${ }^{20}$ The testimony thus has a salutary effect when it corrects popular misconceptions, but has a damaging effect if the jurors turn from overvaluing the eyewitness evidence to overvaluing the expert's testimony questioning it. ${ }^{21}$

18. Admittedly, the framework testimony favors the prosecution, because the general evidence gathered by social science and medical research is that, in fact, the alleged victims of child sexual abuse generally tell the truth and that the defendants are generally guilty. This fact does not, however, mean that every defendant is guilty. Moreover, while the framework evidence may help to screen out some cases where it indicates that the child's particular story is not credible, such favorable screening for the defendant appears to be relatively rare, both because most defendants are in fact guilty and because the framework does not have strong tests to discriminate between truthful alleged victims and those who are fabricating their testimony. Thus, a decision to admit the social framework evidence enhances the prosecution's chances for conviction across the board, as compared with the same case when social framework testimony is excluded.

19. E. Loftus, Eyewitness Testimony 18-19, 177 (1979) (jurors overbelieve eyewitness testimony); Loftus \& Monahan, Trial by Data: Psychological Research as Legal Evidence, 35 Aм. Psychologist 270, 273-74 (1980) (same); Cutler, Penrod \& Stuve, Juror Decision Making in Eyewitness Identification Cases, 12 LAw \& Hum. BeHav. 41, 54 (1988) (concluding "that jurors do not possess the knowledge and skills necessary to adequately assess the reliability of eyewitness identifications"); Wells, Lindsay \& Tousignant, supra note 17, at 279 (mock jurors making credibility determinations do not adequately take into account the conditions surrounding the observation).

20. Wells, supra note 17, at 90-91 (arguing that separate from effects on verdict, expert testimony performs a useful function if it insures that eyewitness testimony is given appropriate weight by jurors).

21. One formulation of this argument is that framework and other similar scientific evidence, which is ostensibly only admitted if appropriately reliable, should be admitted when it combats popular beliefs but not when popular conceptions are in accord with scientific evidence. Cf. Bonnie \& Slobogin, The Role of Mental Health Professionals in the Criminal Process: The Case for Informed Speculation, 66 VA. L. REv. 427, 493-94 (1980) (expert testimony by mental health professionals should be permitted in reconstructive inquiries when offered on behalf of the criminal defendant because, inter 
On the second issue, the framework testimony generally cannot tell jurors much about which eyewitnesses under a given set of observation conditions have made accurate identifications. Assume that under certain observation conditions we can predict that 50 percent of subjects in a controlled setting will select correctly the person who committed a mock crime. The expert can tell the jurors that correct observations under these circumstances will likely occur in one-half of the cases, but, as noted above, the expert can give little guidance in determining which eyewitnesses among the group chose correctly. The evidence is potentially subject to teaching an erroneous lesson-that all of these identifications are to be disbelieved. ${ }^{22}$ The appropriate impact of the testimony therefore depends upon careful calibration to give it only the degree of impact needed to bring juror beliefs into accord with social reality. This limited positive effect may turn negative, however, if the evidence is misunderstood or valued too highly by jurors.

Looking at this array of issues and problems, one can easily see that empirical research is critically important to the correct resolution of admissibility decisions. At the same time, it is obvious that the issues facing researchers and courts in making these judgments are enormously difficult. The analysis that follows examines the efforts of both lawyers and social scientists to grapple with these problems. On the affirmative side, it is clear that the appropriate issues have been identified and that progress is being made by both groups in resolving them. On the other hand, the joint venture has far to go, and, unfortunately, the mechanism available to accomplish the

alia, the prosecution has natural advantages in this area and jurors are typically skeptical of defense explanations).

While at first glance curious, this result may be squared with well-established evidentiary principles. First, evidence that is cumulative on a point will frequently be excluded when the same evidence would have been received if it were the only evidence available to prove the issue. See FED. R. Evid. 403 advisory committee's note ("The availability of other means of proof may also be an appropriate factor."). Second, when the scientific evidence is consistent with popular perceptions, its impact is likely to be exaggerated by the jury.

The result that excludes such evidence when it accords with popular juror views also rests on an additional premise, however. Jurors may not fully appreciate that scientific evidence often lacks certainty. Thus, when popular beliefs and apparent scientific certainty combine, the perceived value of the evidence will likely outstrip its true scientific reliability. In that situation, the evidence should be excluded.

22. Expert testimony in this area may be useful at a second level in correcting jurors' misconceptions about matters such as their own ability to evaluate whether the eyewitness has made a mistake. One study indicates that the jurors are incapable of telling an accurate witness from an inaccurate witness, and, in fact, will believe inaccurate witnesses at a slightly higher level, under some circumstances, than those who were correct. Wells, Lindsay \& Tousignant, supra note 17, at 282. Whether expert testimony theoretically can or will improve that ability to discriminate is open to question, see supra note 17, but it may be helpful in educating the jury that they as jurors are unlikely to be able to tell the difference, at ieast among those witnesses who are sincere in their beliefs.

Psychological research on factors affecting the accuracy of identifications can generally have an entirely beneficial effect when it is used to structure the identification setting that is under the control of the prosecution. Wells, Applied Eyewitness-Testimony Research: System V'ariable and Estimator I'ariables, 36 J. Personality \& Soc. Psychology 1546, 1554-55 (1978) (contrasting "system variables," which are within the control of investigators, with "estimator variables," which are not controllable and are used only to discount or augment credibility). 
task-decisions by judicial officers in the adjudication of individual cases-is ill-suited to the task.

In Part II, I set out the general evidentiary principles used by courts to evaluate the admissibility of social framework testimony. In Part III, I examine the conception of framework testimony developed by Walker and Monahan and argue that a broader definition is appropriate for use in analyzing the admissibility issues raised by this general class of evidence. In Part IV, I analyze the case law in the area of child sexual abuse and cases involving adult victims of rape. I also compare the courts' analyses in these two areas using illustrative pairs of cases from two jurisdictions, and highlight the apparent empirical assumptions underlying their decisions. Finally, in Part V, I set out some broad categories of factors that courts find important in deciding whether to admit evidence in these two areas. My conclusion is that courts are more willing to admit social framework evidence in child sexual abuse cases than in rape cases where the victim is an adult female. This difference is not fully explained by empirical evidence that shows either a greater need for the evidence in cases involving children or the greater reliability of empirical research regarding framework evidence in child sexual abuse cases. I speculate that the difference in admissibility is explained rather by an intense feeling shared by judges about the evil of child sexual abuse as a social phenomenon.

In another area, I note that courts generally exclude social framework evidence when it bears directly upon issues of witness credibility. Again, I suggest that enhanced judicial sensitivity where credibility is directly involved is not based on a precise empirical foundation, but rather on deeply held views about the appropriate role of the jury in our trial process. I also identify a number of specific characteristics of the social framework evidence that play a more narrow role in the admissibility determinations of courts regarding such evidence. Looking at the entire area treated in this article, my overall conclusion is that, while the results reached by the courts appear to respond in a general fashion to appropriate empirical and doctrinal concerns, the analysis employed is unfortunately only loosely connected to those concerns.

\section{II}

\section{Basic Modes of Evidentiary Analysis}

In analyzing the admissibility of social framework evidence, courts use a number of different modes of evidentiary analysis. While the concepts involved frequently overlap, the categories discussed below each have an independent focus worthy of attention. 


\section{A. The Frye Test}

The so-called Frye ${ }^{23}$ test requires that, before evidence of a novel scientific principle is admissible, the scientific principle must "have gained general acceptance in the particular field in which it belongs." 24 The test serves two major and several minor functions. First, it establishes a method of determining and ensuring the reliability ${ }^{25}$ of scientific evidence. ${ }^{26}$ Second, while not directed by the terms of the decision to focus on this issue, ${ }^{27}$ courts generally apply the Frye test in a fashion that mandates a high threshold of reliability for types of scientific evidence viewed as likely to overwhelm the jury. Indeed, recently the Ninth Circuit used the tendency to overwhelm as defining when the Frye test was required:

[E]xpert testimony based on play therapy with anatomically correct dolls must qualify under the Frye test because the trier of fact would tend to ascribe a high degree of certainty to the technique. ${ }^{28}$

The general analysis of courts here is that, where scientific evidence has a substantial likelihood of being treated as authoritative by the jury, the reliability of that evidence must be high to avoid the possibility of the jury's overvaluing the evidence. ${ }^{29}$

Supporters of the Frye test also cite two secondary advantages that generally protect the adversary process and help to ensure its effectiveness in

23. Frye v. United States, 293 F. 2d 1013 (D.C. Cir. 1923).

24. Id. at 1014 .

25. In the same way that most courts use the term, I shall use "reliability" throughout this paper to convey the general sense that is conveyed by the terms "validity" and "reliability" in scientific terminology. In scientific writing, validity refers to the accuracy of the technique in measuring what it is intended to measure. Reliability means the consistency of the technique in measuring accurately the phenomenon. Giannelli, The Admissibility of Novel Scientific Evidence: Frye v. United States, a Half Century Later, 80 Colum. L. Rev. 1197, 1201 n.20 (1980). Legal use of the term reliability appears to convey a meaning that is an amalgamation of the two scientific terms, although courts often do not elucidate its precise meaning.

26. Id. at 1207.

Frye is cited as avoiding a situation, feared by some courts, where the trial judge would be forced to accept the determination of any qualified witness that scientific evidence has probative value. Doyle, Applying Lawyers' Expertise to Scientific Experts: Some Thoughts about Trial Court Analysis of the Prejudicial Effects of Admitting and Excluding Expert Scientific Testimony, 25 WM. \& MARY L. Rev. 619, 633 (1984); see also Strong, Questions Affecting the Admissibility of Scientific Evidence, 1970 U. ILL. L. REv. 1, 22. That fear seems somewhat overdrawn since, even absent the Frye test, courts are not obliged to surrender the ultimate decision to the expert. Moreover, even under Frye, the courts must, in the final analysis, defer substantially to expert opinion. The major difference between the two situations is at what point, as to what issue, and to what degree the court must defer.

27. The Frye test is, by its terms, to be applied to novel scientific evidence, not to evidence likely to be overvalued or misused. Theoretically, its application should not coincide perfectly with a substantive concern for overvaluing. Indeed, inconsistency and indeterminacy in deciding when Frye should apply under any clearly defined standard have been among the major weaknesses of the test. See Giannelli, supra note 25, at 1219-21 (inconsistencies and selective application of test a major difficulty).

28. United States v. Gillespie, 852 F.2d 475, 481 (9th Cir. 1988) (emphasis added).

This second function may more accurately be satisfied by application of Rule 403 , which is discussed below. See MCCormick on Evidence \& 203, at 609 (3d ed. 1984) (relevancy analysis, unlike general acceptance test, is sensitive to perceived degree of prejudice flowing from the evidence).

29. See, e.g., State v. Roscoe, 145 Ariz. 212, 218-220, 700 P.2d 1312, 1318-19 (1984) (en banc) (testimony concerning use of dog to identify items by "sniff" not subject to Frye test because no danger that jury would treat "sniff" as scientifically infallible), cert. denied, 471 U.S. 1094 (1985). 
testing the scientific evidence. First, application of the Frye test helps to avoid the time-consuming task of determining, through the receipt of evidence and a battle of experts in numerous individual cases, the reliability of the scientific technique or principle involved. ${ }^{30}$ Second, it ensures "a minimal reserve of experts who can critically examine the validity of a scientific determination in a particular case," 31 which facilitates the adversary presentation of conflicting views and the vigorous testing of the technique.

Frye's continued vitality in the legal analysis of social framework evidence in many states $^{32}$ is somewhat remarkable considering that the Federal Rules of Evidence do not even mention it. ${ }^{33}$ Its survival is probably explained by its ability to produce results congenial to the courts' basic misgivings about novel scientific evidence, including some that falls within the broad category of social framework testimony.

With regard to the accuracy of admissibility determinations produced by the Frye test, the two critical variables are, first, the tendency of the social framework evidence to overwhelm the jury, and second, the reliability of the evidence. ${ }^{34}$ At a secondary level, the attractiveness of the Frye test is related to the relative inaccessibility of social science research to the courts, both in terms of the courts' ability to gain ready access to the research and their capacity to understand and use it. ${ }^{35}$ Frye survives, to some extent, because of courts' fears that without its easy method of determining scientific reliability

30. Giannelli, supra note 25 , at 1207.

31. United States v. Addison, 498 F.2d 741, 744 (D.C. Cir. 1974).

32. For example, recently in Gillespie, 852 F.2d at 480-81, and State v. Black, 109 Wash. 2d 336, 342, 745 P.2d 12, 15 (1987), courts applied the Frye test to expert testimony relating to social frameworks in the area of child sexual abuse and rape. However, Frye has not remained the test for admissibility in other jurisdictions. During the same period, two other courts rejected Frye. See State v. McCoy, 366 S.E.2d 731, 736 n.9 (W. Va. 1988); People v. Hampton, 746 P.2d 947, 951 (Colo. 1987).

33. The uncertainty surrounding whether Frye survived the promulgation of the Federal Rules of Evidence is a tribute to the indeterminacy of rules of statutory construction. Those who claim that it survived cite the failure of even the advisory committee notes to the Federal Rules to mention Frye, arguing that such a major change in the existing law cannot be presumed from silence. See $\mathbf{S}$. Saltzburg \& K. Redden, Federal Rules of Evidence Manual 633 (4th ed. 1986). See also McCormick, Scientific Ezidence: Defining a New Approach to Admissibility, 67 IowA L. REv. 879, 888 (1982) ("nothing in the [Federal Rules of Evidence], their history, or the advisory committee comments discloses an express intention to repudiate the Frye test"). Those who argue that Frye was supplanted by Rule $\mathbf{4 0 3}$ of the Federal Rules also cite the silence of the Rules and commentary as supportive. Frye, they argue, is inconsistent with the thrust of the Federal Rules and can only continue to apply if affirmatively sanctioned by the Rules. See United States v. Downing, 753 F.2d 1224, 1234-35 (3d Cir. 1985).

34. Clearly, general acceptance is not the same as reliability, and to equate the two is essentially to abandon the Frye test in favor of a reliability test, which fits within the relevancy analysis discussed in Part $C$ infra. Giannelli, supra note 25, at 1220. However, general acceptance does correlate with high reliability, and courts often use Frye "as a label to justify their own views about the reliability of particular forensic techniques." Id. at 1221 .

35. But of. Walker \& Monahan, supra note 1, at 588-91.

Institutional methods of proceeding and judicial thought patterns in dealing with evidence may make it difficult for courts to use other types of technical evidence, such as statistical evidence. See Some Lessons: The Institutional Competence of Courts, in Evolving RoLE, supra note 9, at 72, 83. Thus, the impetus to use Frye to protect against the intrusion of evidence that is difficult for courts to understand and utilize is by no means limited to framework evidence. 
they will be left at the mercy of whatever expert happens to be most readily available. To this extent, if scientific literature is accessible to the courts and they are able independently to evaluate it, the perceived benefits of the archaic Frye test should be reduced.

\section{B. Beyond the Ken of the Jury or, Alternatively, Helpfulness}

Under traditional common law analysis, scientific evidence was admissible only if the subject of the testimony was "beyond the ken" of the average juror. Theoretically, experts were not permitted to interpret data for the jury when the jurors themselves were capable of understanding the same information. Under more modern evidentiary analysis, the requirement that the subject matter must be entirely beyond the competency of the jury has been abandoned in favor of a much less exacting requirement that the testimony be helpful to, or assist, the jury in its evaluation of the evidence. ${ }^{36}$ The empirical questions presented are, first, the relative ignorance of the jurors as to a social condition that will be corrected by introduction of the framework evidence and, second, the jurors' ability properly to understand and use the data presented. ${ }^{37}$

36. See FED. R. EVID. 702 advisory committee's note:

There is no more certain test for determining when experts may be used than the common sense inquiry whether the untrained layman would be qualified to determine intelligently and to the best possible degree the particular issue without enlightenment from those having a specialized understanding of the subject involved in the dispute.

Ladd, Expert Testimony, 5 VAND. L. REv. 414, 418 (1952). When opinions are excluded, it is because they are unhelpful and therefore superfluous and a waste of time. $7 \mathrm{~J}$. Wigmore, EvidenCE $\$ 1918$ (Chadbourn rev. 1978). See also id. at $\S 1923$, at 29 (The appropriate test is whether "on this subject can a jury from this person receive appreciable help."); $3 \mathrm{~J}$. Weinstein \& M. Berger, WEinstein's EVIDENCE \$ 702[02], at 15-16 (1988) (“[E]ven when jurors are well equipped to make judgments on the basis of their common knowledge and experience, experts may have specialized knowledge to bring to bear on the same issue....").

37. Correcting juror ignorance about a social phenomenon is a somewhat unusual goal for the legal system. A juror may be excluded from service if he has biases that "would prevent or substantially impair the performance of his duties as a juror in accordance with his instructions and his oath." Adams v. Texas, 458 U.S. 38, 45 (1980). The advocates are entitled to inquire themselves or to have the court ask questions to determine whether such biases exist. However, with regard to the fund of general information possessed by prospective jurors, the law appears to be uncertain. Specific knowledge of the facts of a particular case may, of course, be grounds for disqualification, and a case is not to be determined by such specific knowledge. See Irvin v. Dowd, 366 U.S. 717, 72223 (1961). However, when it comes to the store of basic information available to jurors for their use in evaluating evidence presented-the general body of information that helps produce what may be called the common experience or common sense of jurors-the law has been much less clear on what is expected of, and permitted by, jurors. Compare Downing v. Farmers' Mutual Fire Insurance Co., 158 lowa 1,138 N.W. 917 (1912) (case reversed because jurors instructed that they could consider their own observations and experience in determining whether to accept expert testimony concerning cause of death of livestock), with Solberg v. Robbins Lumber Co., 147 Wis. 259, 133 N.W. 28 (1911) (jurors properly instructed that they could use their personal knowledge). See generally MCCormick on Evidence, supra note 28 , $\$ 329$, at 923-24.

Social framework evidence often seeks to correct either specific factual or logical misunderstandings that prospective jurors hold in common with others in society that may interfere with their ability to evaluate evidence correctly. This effort to fine tune juror common knowledge by the introduction of expert testimony as opposed to assuming that adequate experience exists in the jury as a whole to evaluate adequately the evidence in the case appears new to the law and raises a set of knotty theoretical and practical problems. See, for example, the debate between Professors Gold and Tanford over the existence and extent of the dangers involved in the expanded use of 
If this helpfulness standard were applied literally and the court considered only the benefits possible through the testimony, the expert's testimony concerning a relevant social condition would be found helpful unless the jury were as knowledgeable as the expert or as able as the expert to interpret technical evidence. However, in applying the helpfulness requirement, courts have looked not only at the potential benefits of the testimony. Instead, they have both explicitly and implicitly weighed the potential aid the jury would receive from the expert's testimony against the possibility that such testimony would have a distorting influence on the trial process in terms of consumption of time, injection of distracting side issues (such as expert competence), and, particularly, creation of the potential for overvaluation of the expert's testimony. ${ }^{38}$

The empirical issue thus becomes one of the value of the expert in dispelling ignorance or helping to evaluate evidence, which is a function of the quality of the expert's data and analysis, the degree of ignorance on the part of the jury of the social phenomenon, and the difficulty of the evaluative task. These factors are weighed against the distorting influence that may be produced by expert testimony on the issue.

The helpfulness test as applied to expert testimony that a witness is testifying truthfully or falsely deserves special attention. Courts often purport to apply a pure helpfulness standard in this area without any reliance upon concepts such as overvaluation. In rejecting the testimony, the argument typically accepted is that the expert has no special ability beyond

psychologists by lawyers in selecting and influencing jurors. Gold, Covert Advocacy: Reflections on the Use of Psychological Persuasion Techniques in the Courtroom, 65 N.C.L. Rev. 481 (1987); Tanford \& Tanford, Better Trials through Science: A Defense of Psychologist-Lawyer Collaboration, 66 N.C.L. REv. 741 (1988).

38. See State v. Moran, 151 Ariz. 378, 382-86, 728 P.2d 248, 252-56 (1986) (testimony of expert, inter alia, that child's behavior consistent with sexual abuse having occurred inadmissible under Arizona Rule 702 as not assisting jury because it conveyed expert's belief in credibility of victim); People v. Hampton, 746 P.2d 947, $951-52$ (Colo. 1987) (given fact that expert opinion was limited with regard to reactions of rape victims generally and was not used to establish that crime was committed, testimony properly received under Colorado Rule 702); Wheat v. State, 527 A.2d 269, 272-75 (Del. Sup. 1987) (initial question under Delaware Rule 702 is whether expert testimony on intrafamily child sexual abuse will assist jury in understanding evidence, but to be admissible such evidence must be limited to general behavioral factors and may not suggest quantification of veracity determination as it carries too much potential for credibility enhancement); State v. Hester, 114 Idaho 688, 695-96, 760 P.2d 27, 34-35 (1988) (testimony identifying attacker invades jury's function rather than assisting it and is inadmissible under Idaho Rule 702); State v. McCoy, 366 S.E.2d 731, 736-37 (W. Va. 1988) (under West Virginia Rule 702, testimony concerning symptoms of rape trauma syndrome admissible, but opinion that the victim was raped inadmissible because it encroaches too powerfully upon jury's role in determining credibility; confusing or misleading testimony properly excluded under Rule 702).

Whether the issues of consumption of time, confusion of the issues, and overvaluation of expert testimony are properly considered as a part of the helpfulness inquiry or should be confined to a relevancy analysis is not clear. Courts clearly do amalgamate the two issues, and they weigh these factors in applying the helpfulness test, which otherwise would be almost automatically met, assuming the expert had any special knowledge, training, or experience, beyond that of the jurors, relevant to an issue in the case. 
that of lay people to determine whether a witness is lying. ${ }^{39}$ That argument alone, however, does not entirely explain the frequency with which courts exclude the testimony. Rather, the importance of the credibility issue affected by the evidence comes into play, ${ }^{40}$ as well as a concern for possible overvaluation of the expert's testimony. Finally, courts appear to be deeply concerned that expert opinions on credibility will have an undesirable effect upon the role of the jury in assessing authoritatively the credibility of witnesses and will thereby subvert the important values, beyond those of accurate factfinding, ${ }^{41}$ that a jury verdict serves.

In addition to the modern helpfulness interpretation of the "beyond the ken" concept, some courts employ several additional, somewhat related, tests, particularly in the area of credibility. First, they rule that expert testimony should not be admissible when "the state of the pertinent art or scientific knowledge does not permit a reasonable opinion to be asserted even by an expert."42 This test better explains the exclusion of some expert testimony on credibility than a pure helpfulness test, since the courts appear to be saying that no one can give a reasonably reliable opinion in this area, rather than that an expert can make no better assessment than a layman.

Second, the testimony of the expert is occasionally excluded under the argument that an expert opinion that a sexual assault on a child occurred, for example, improperly "convert[s] hearsay declarations into admissible opinions." 43 As a general matter, modern evidentiary analysis finds nothing improper in an expert relying on inadmissible hearsay to form an opinion. ${ }^{44}$ This objection accordingly should be viewed as largely a restatement in different terms of the valid objection given immediately above-hearsay may not be relied upon to form an opinion where the expert does not have sufficient expertise to reach a reasonable opinion. In effect, the courts are saying here that experts are not sufficiently more adept at evaluating the credibility of witnesses than jurors when their opinions are based on

39. See, e.g., United States v. Azure, 801 F.2d 336, 341 (8th Cir. 1986) ("No reliable test for truthfulness exists and [the expert] was not qualified to judge the truthfulness of that part of [the witness'] story.").

40. Fed. R. Evid. 704 eliminated any explicit restriction on testimony concerning an "ultimate issue," except in the limited context of an insanity defense to a criminal charge. It did not eliminate, however, the greater sensitivity of the courts to opinions that affect important issues in the cases. Cf. MCCormick on Evidence, supra note 28, $\$ 12$, at 30 (courts tend to be more liberal in allowing opinions where facts are collateral to important issues but tend to require concrete details as to more crucial matters).

41. For further discussion of these values, see infra notes 83-86 and accompanying text.

42. McCormick on Evidence, supra note 28, § 13, at 34. See also Dyas v. United States, 376 A.2d 827,832 (D.C.), cert. denied, 434 U.S. 973 (1977) (quoting MCCormick on EvidenCE $\$ 13$, at 31 (2d ed. 1972)); McCord, supra note 14, at 86 ("The most used alternative to the Frye test is the Dyas test.').

43. State v. Hester, 114 Idaho 688, 695, 760 P.2d 27, 34 (1988). Some courts alternatively view such an opinion as constituting testimony on the credibility of the witness, focusing on the fact that the major basis of the opinion is the witness' statement to the expert. See McCord, supra note 14, at 42 n.82.

44. See, e.g., State v. Allewalt, 308 Md. 89, 98-99, 517 A.2d 741, 745-46 (1985). 
statements by witnesses in the case. The result is that opinions depending critically upon judgments of witness credibility may be excluded. ${ }^{45}$

Finally, expert testimony may not be admitted when the testimony creates the danger that expert testimony will mislead the jury concerning legal issues. ${ }^{46}$ In prosecutions for rape, some courts exclude expert testimony that the victim suffered from rape trauma syndrome on the basis that such testimony improperly employs a legal conclusion that may be misleading or may be misunderstood. Specifically, consent in rape cases is defined in many states from the point of view of the defendant's reasonable, good faith perception. Since the incidence of rape trauma syndrome should relate to the victim's perception of whether she in fact consented and not the defendant's view, if they differ, the conclusion reached by the expert concerning what has been labeled as "rape trauma" may connote not only a legal determination but also a determination under an erroneous standard. The expert's conclusion appears to concern the legal issue to be decided by the jurors, but, in fact, the term "rape" is defined differently by the expert. ${ }^{47}$ The existence of this potential source of misunderstanding has led some courts and commentators to utilize terminology that avoids the appearance of reaching a legal conclusion. ${ }^{48}$

\section{Relevancy}

Modern evidence law defines relevancy according to two factors. First, the fact to which the evidence arguably relates must be of consequence to the outcome of the case and must make that consequential fact more or less likely

45. But cf. Mosteller, Child Sexual Abuse and Statements for the Purpose of Medical Diagnosis or Treatment, 67 N.C.L. REv. 257, 261-64 (1989) (noting that one possible trustworthiness rationale for admission of hearsay statements to medical experts consulted only for diagnosis and not for treatment is that such experts have special expertise in evaluating the accuracy of the data given them because of their training and experience).

46. See FED. R. Evid. 704 advisory committee's note: "The abolition of the ultimate issue rule does not lower the bars so as to admit all opinions. Under Rules 701 and 702 , opinions must be helpful to the trier of fact .... These provisions ... stand ready to exclude opinions phrased in terms of inadequately explored legal criteria."

47. People v. Bledsoe, 36 Cal. 3d 236, 250 n.12, 681 P.2d 291, 300 n.12, 203 Cal. Rptr. 450, 459 n. 12 (1984).

Courts raise a related, but conceptually distinct, objection that the use of the terminology "rape trauma syndrome" may mislead the jury in the sense of being overvalued because they may believe that "such a classification reflects a scientific judgment that the witness was, in fact, raped." Id. at 251 n.14, 681 P.2d 301 n.14, 203 Cal. Rptr. 460 n.14. See also Allewalt, 308 Md. at 102-03, 517 A.2d at 751 (unfair prejudice largely reduced when expert does not use "rape trauma" terminology because it does not equate the syndrome exclusively with rape); State v. Taylor, 663 S.W.2d 235,240 (Mo. 1984) (en banc) (testimony concerning "rape trauma" syndrome appears to give scientific certainty to the fact that the trauma causing witness' condition was a rape). Expert testimony regarding whether a rape occurred does not, however, run afoul of another fundamental limitation encountered when expert testimony is offered on an insanity defense. Expert testimony on the ultimate issue of criminal responsibility may be seen as involving normative as well as empirical judgments, the former involving moral determinations that are beyond clinical expertise. See Bonnie \& Slobogin, supra note 21 , at 456.

48. Massaro, supra note 3, at 450-52 (suggesting the use of "post-traumatic stress disorder" instead of rape trauma syndrome). 
than it would be in the absence of the testimony. ${ }^{49}$ Second, the prejudice, confusion, delay, and distortion resulting from the admission of relevant evidence must not substantially outweigh its probative value. ${ }^{50}$ In most situations, the first relevancy factor is easily established whereas prejudice concerns are more complicated and difficult to resolve.

Nevertheless, even when ostensibly dealing only with the first set of questions, some courts have excluded social framework evidence under the theory that it has no relevancy to the case. They object to the framework testimony because it is derived from general studies concerning a broad group and does not concern the particular individual or the specific conduct of that individual in the case. ${ }^{51}$

Whether a relevancy objection in the narrow sense posed by the first set of questions is valid depends upon two issues. First, is it possible to use probabilistic evidence generally or group behavior specifically to guide a factfinder in determining whether an event happened in the past, as opposed to using such evidence to predict what will happen in the future? In theory, there should be no significant difference in the use of such data to perform the two tasks. ${ }^{52}$ Second, will knowledge about group performance shed light on the likelihood of the behavior at issue in the case on trial?53 The answer here depends largely upon the accuracy of the general grouping of people who display relevant behavior or characteristics and the correspondence between the relevant participant in the case and that group. While some minimal level of scientific validity and reliability of the categorization must be met, and jurors, either alone or with expert assistance, must be able at some minimal level to determine whether the individual possesses the relevant characteristic, as a matter of relevancy as described in Federal Rule of Evidence 401, the issue is easily resolved.

Assuming the evidence satisfies the initial relevancy inquiry, one then encounters the more difficult issue of what "prejudice" may flow from admission of the evidence. This is not "prejudice" in the strict sense of exciting an emotional reaction as it is defined in the Federal Rules. ${ }^{54}$ Scientific evidence generally, or social framework testimony in particular,

49. These issues are raised by Federal Rule of Evidence 401.

50. The Federal Rules of Evidence treat these questions under Rule 403

51. The reasoning in State v. Saldana, 324 N.W.2d 227, 230 (Minn. 1982), is suggestive of this approach: "The jury must not decide this case on the basis of how most people react to rape ... [but rather] the jury must decided what happened in this case ...."

52. "[P]ropositions about past facts ... [can be regarded as] 'predictions,' on existing information, as to what the 'truth' will turn out to be when and if more knowledge is available." Ball, The Moment of Truth: Probability Theory and Standards of Proof, 14 VAND. L. REv. 807, 815 (1961) (footnote omitted). See also Tribe, supra note 5, at 1345-46; Walker \& Monahan, supra note 1, at 57475.

53. The theory supporting admissibility is that one may generalize from the behavior of a relevant group to the likely behavior of an individual member of that group. The validity of the inference depends critically upon the fact that the group is similar to the individual with regard to some specific feature that relates positively to the behavior or condition at issue.

54. "'Unfair prejudice' within this context means an undue tendency to suggest decision on an improper basis, commonly, though not necessarily, an emotional one." FED. R. EvID. 403 advisory committee's note. 
rarely excites strong emotional reactions. ${ }^{55}$ Rather, the chief concern is with juror overvaluation of the testimony of an expert resulting chiefly from the aura of science associated with that testimony. ${ }^{56}$ Whether valuation is excessive is, of course, a relative determination and depends upon the value of the inference drawn as compared with its impact on the jury. It obviously involves both an examination of the reliability of the social framework testimony, the quality of the linkage between that framework and a relevant individual in the case, and the potential for jurors to give the testimony inappropriate weight. ${ }^{57}$

The analysis of relative valuation often is quite difficult both in terms of the legal and the empirical issues and raises questions related to the precise form in which the evidence will be presented. An important concern here is whether particularized testimony will be offered about an individual in the case based on clinical examination by an expert or whether only social framework evidence will be offered without the expert directly linking the framework to the individual.58 The potential for the evidence to be overvalued is likely to be less when the expert testifies only to general results than when he or she explains concretely the application of that data to the

55. Walker \& Monahan, supra note 1, at 575-76.

56. Secondary concerns pertain to the consumption of time and confusion of issues when experts battle, when contests are waged over the credentials of experts, and when the quality of the science involved is subject to conflicting claims.

57. Adding to the difficulty of both gauging and controlling the impact of social framework evidence on the jury is the intrinsic difficulty of educating lay jurors on some aspects of the empirical basis and significance of such evidence. I offer here no empirical data but rather the anecdotal experience of some instructors who find it very, very difficult to explain effectively to college and law student audiences how to interpret data that involve the use of base rates. Whether this difficulty leads to excessive valuation or complete rejection of the evidence is unclear and, I suspect, dependent upon factors that vary almost independently of the reliability of the data, such as demeanor of the expert giving the explanation.

58. Courts differ as to whether it matters for the purpose of admissibility that the expert provides a direct opinion concerning the victim or gives instead only social framework testimony. As to some issues, the form of the testimony is considered important by the courts. For example, some courts permit admission of the expert's opinion that a child was the victim of a sexual assault. State v. Hester, 114 Idaho 688, 692-93, 760 P.2d 27, $31-32$ (1988); Townsend v. State, 103 Nev. 113,118 , 734 P.2d 705, 708, (1987); State v. Bailey, 89 N.C. App. 212, 219, 365 S.E.2d 651, 655-56 (1988). Other courts will not allow testimony that an assault occurred but will permit general testimony concerning the characteristics of children who have been sexually assaulted from which the jury may infer that the victim was assaulted. State v. Moran, 15I Ariz. 378, 384-86, 728 P.2d 248, 254-56 (1986); People v. Roscoe, 168 Cal. App. 3d 1093, 1099-1100, 215 Cal. Rptr. 45, 49-50 (Cal. Ct. App. 5th Dist. 1985).

As to other issues, such as testimony concerning the credibility of the witness, this distinction is critical, and only general social framework evidence as opposed to a direct opinion about the witness stands much chance of being received. See, e.g., State v. Lindsey, 149 Ariz. 472, 474-75, 720 P.2d 73, 75-76 (1986) (en banc) (direct testimony on credibility not permitted, and even testimony giving statistics concerning children's veracity improper, but general patterns of child behavior relevant to credibility without a statistical base admissible); Wheat v. State, 527 A.2d 269, 274-75 (Del. Sup. 1987) (same); State v. Oliver, 85 N.C. App. I, 11 , 354 S.E.2d 527, 533, disc. rev. denied. 320 N.C. 174 , 358 S.E.2d 64 (1987) (expert cannot give direct testimony that child witness is believable but may give testimony concerning general credibility of children). See also State v. Woodburn, 559 A.2d 343. 346 (Me. 1989) (expert testimony on child witness' credibility properly excluded because lacking in "scientifically accepted basis"). 
behavior of a witness in the case. ${ }^{59}$ Other variations in the form of the testimony should also enhance this likelihood of overvaluation, such as the use of explicitly statistical proof, and the presence of mechanically produced displays with an imposing appearance. ${ }^{60}$

Aside from explicit concerns about the impact of the form of the testimony on juror overreaction to framework evidence, relevancy analysis must be concerned with how the individual and the social group are shown to correspond as to some relevant feature. As noted above, the probative value of the social framework testimony rests upon the similarity with regard to some important characteristic between a participant in the case and the members of a social group. In some cases, where the correspondence between the group and the individual is obvious on a feature that the expert will testify is critical, this aspect of the relevancy issue is easily resolved. Relevancy exists if the principle involved itself is valid and the technique used is an effective method for producing the result indicated under the proper operation of that principle. In other situations, where the very existence of the correspondence between critical features is subject to doubt, is not determinable directly by the jury, or corresponds with the disputed issue in the case, the issue is far more complicated. ${ }^{61}$

59. Professors Vidmar and Schuller discuss studies that indicate that the manner of presentation of social framework evidence has critical impact upon its effect on the jury. Vidmar \& Schuller, Juries and Expert Evidence: Social Framework Testimony, LAw \& Contemp. Probs., Autumn 1989, at 133. Professor Schuller's own study indicates that only when the testimony concerning the description of the battered woman syndrome was connected to the case through a specific diagnosis did the evidence have substantial impact upon mock jurors' decisions. Id. at 152-53. Professors Brekke and Borgida found similarly that mock jurors made the most use of expert testimony concerning rape when it was linked to the case through a specific hypothetical example and was presented early in the case. Brekke \& Borgida, Expert Psychological Testimony in Rape Trials: A Social-Cognitive Analysis, $55 \mathrm{~J}$. Personality \& Soc. Psychology 372, 376-77 (1988).

Presumably greater effectiveness of the expert testimony gives rise to a correspondingly greater likelihood of overvaluation.

60. See Imwinkelried, A New Era in the Evolution of Scientific Evidence-A Primer on Evaluating the Weight of Scientific Evidence, 23 WM. \& MARY L. REv. 261, $272-87$ (1981) (suggesting categories of scientific evidence according to certain general characteristics relating to the weight jurors may ascribe to them). See also State v. Schwartz, 447 N.W.2d 422, 428 (Minn. 1989), and State v. (Joon Kyu) Kim, 398 N.W.2d 544, 547-49 (Minn. 1987), which exclude population frequency statistics from expert testimony interpreting the results of blood tests $(\mathrm{Kim})$ and DNA typing (Schwartz) as methods of identification because of the potential of such evidence to have an exaggerated impact on the jury.

61. Let us use rape trauma syndrome as an example. First, in the easiest case, the parties do not disagree on the issue of whether the victim was raped. The defendant may concede that the victim was indeed raped but contests identity. The victim's membership in a group of victims is thus established by agreement. However, another critical element of relevancy analysis may be eliminated as an indirect result of the stipulation. The social framework evidence may have nothing to say that makes a fact of consequence more or less likely. The rape trauma syndrome would generally tell us nothing about the specific identity of the attacker, which is the only issue contested by the defendant. What it tells us about consent goes to an issue that is not contested. As a result, while the evidence is technically not irrelevant under Federal Rule of Evidence 401, confusion will outweigh probativity under Rule 403, and the evidence should be excluded. See FED. R. Evid. 401 advisory committee's note.

Second, consent may be contested and the expert may testify from his or her clinical examination and from knowledge of social framework information that the complaining witness was the victim of a rape or exhibits certain features consistent with the general behavior of the group of women who have been raped. Given that testimony, the social framework testimony tells us, in the first situation, that it is more likely that the complaining witness was the victim of a rape and, in the second 
Three questions are implicated here: How easily is the correspondence determined? How central is the determination of that correspondence to the outcome of the case? How likely is it that the jury will presume the defendant's guilt from the existence of a scientifically defined social grouping with apparently relevant characteristics and some plausible correspondence between the witness' characteristics and those of the group? 62

In summary, since the prejudice of chief concern in this area is the potential overvaluation of expert scientific evidence by the jurors, the most important issue for legal relevancy is the proper valuation of the evidence by the jury. The analysis is not one of absolute values but one of comparative weight. ${ }^{63}$ The key questions are: Precisely how reliable is the scientific result being applied? (This question includes not only the general research, but also the fit between the social framework and a relevant individual. ${ }^{64}$ ) How impressive will the jury find this evidence? The empirical issues raised here become very specific and complicated. The form of the testimony, a subject on which empirical research is only beginning, may be the most critical

instance, that the fact that the complaining witness displayed certain specific behavior makes it more likely that she was raped. The major concern here is that in identifying the complaining witness directly or inferentially as a member of the group of rape victims, the expert is expressing an opinion central to the ultimate outcome of the case. Drawing the connection between the classification and the individual, which is essential to the relevancy of the social framework information, may produce prejudice because the drawing of that connection is the central issue in the case. See People v. Bledsoe, 36 Cal. 3d 236, 250 n.14, 681 P.2d 291, 301 n.14, 203 Cal. Rptr. 450, 460 n. 14 (1984) (rape trauma syndrome may erroneously convey to jury that "such a classification reflects a scientific judgment that the witness was, in fact, raped"); State v. Taylor, 663 S.W.2d 235, 240 (Mo. 1984) (en banc) (same).

Third, consent may be contested but, instead of expressing a direct or indirect opinion on the complaining witness' membership in the group of rape victims, the expert may leave that determination to the jury. The expert in this situation would give a general description of the characteristics of a group, and the jury may be asked to draw from the evidence the relevant facts and determine whether the witness has those characteristics. If the jury can adequately draw an appropriate conclusion as to the individual's membership in the group, fewer dangers exist from use of the social framework testimony.

Since this third form of evidence presents the fewest problems in terms of concerns under Federal Rule of Evidence 403, it appears clearly to be the preferable form. And, indeed, the form of the testimony is often critical for admissibility. See supra note 58. Unfortunately, such evidence, see supra note 59, is also likely to be less effective. Accordingly, unless this form of the testimony is required by prejudice concerns, a party should not be limited to it.

62. See Tribe, supra note 5, at 1366 (arguing that when statistical data are introduced on the issue of identity, jurors have a tendency to lose sight of non-quantified issues such as intent-"the hard variables tend to swamp the soft").

63. For an effort to apply a system that compares the reliability of the evidence to the jury's tendency to mis-evaluate it in relation to the hearsay rule, see Note, The Theoretical Foundations of the Hearsay Rules, 93 HaRv. L. Rev. 1786 (1980).

64. Another issue that relates to the value of the evidence is the extent of juror misinformation concerning the relevant social phenomenon that could be corrected by the framework testimony. This issue relates not to the tendency of the evidence to prove a fact but to the degree that the fact needs to be proved, which turns on juror knowledge that predates presentation of evidence in the particular case.

While appearing very similar to the concerns discussed in this section under relevancy, the degree of juror misconception relates more directly to the analysis of the helpfulness of the expert's testimony, discussed in the preceding section. As noted there, courts tend to amalgamate concerns relating to helpfulness and relevancy, see supra notes 37.38 and accompanying text, and this is as it should be, since the issues, while often distinct in other areas, overlap considerably when determining the admissibility of social framework testimony. 
determinant. As noted above, an important issue is whether the testimony is specific to the witness and is based on clinical examination or is presented as general data concerning group characteristics, which the jury is asked to apply to the individual. Also, forms of testimony may vary with regard to how scientific they appear to be; some may have a particularly powerful impact upon a jury because they appear to carry a message of infallibility. Whether the characteristics of testimony that affect the likelihood of overvaluation can be generalized from one area and type of social framework evidence to another remains unclear. ${ }^{65}$

\section{Character Evidence}

Dean McCormick defined character as "a generalized description of a person's disposition, or of the disposition in respect to a general trait such as honesty, temperance or peacefulness." 66 Historically, the law of evidence has strictly controlled the admission of character evidence and has required that it be proved in certain specified and rather stylized forms.

Evidence of character is not excluded because it is irrelevant in the sense that it lacks any tendency to make the existence of a fact of consequence more or less likely. ${ }^{67}$ Rather, it is excluded in most situations because its probativity is considered as relatively slight and its potential for prejudice relatively great. ${ }^{68}$

The traditional treatment of character evidence may have broad importance for the admissibility of social framework evidence. One may argue that social framework evidence generally resembles character evidence and should be admissible according to rules similar to those governing character evidence. The argument is that just as character may indicate a propensity for an individual to act in a certain way, social framework evidence about a relevant group provides guidance in predicting individual conduct. ${ }^{69}$ If this analogy is accepted, a whole set of rules concerning admissibility of social framework testimony could follow. Such rules could include: the exclusion of almost all such evidence from civil cases except that pertaining to credibility; the restriction that evidence enhancing credibility could only be admitted after certain types of attacks on the witness' credibility; and the limitation that only a criminal defense could initiate the introduction of

65. Whether social scientists will be able to reach conclusions that can be easily generalized remains unclear. Unfortunately, it appears that at this point judicial analysis is poorly suited for generalization from one decision about admissibility in one field of social framework testimony to those in another. See Massaro, supra note 3, at 464 (arguing that because judicial opinions describe so poorly the differences between expert testimony that produced the determination on admissibility, reasoning from earlier opinions by analogy and comparison will be difficult); McCord, supra note 14, at 92 (admissibility decisions will require "hard work" by the courts, with careful analysis of particular facts of cases, societal attitudes, and psychological research literature).

66. MCCormick ON Evidence, supra note 28, § 195, at 574.

67. See Fed. R. Evid. 401.

68. MCCormick on EvidenCE, supra note $28, \S 186$, at 549

69. See Walker \& Monahan, supra note 1 , at 581 . 
character evidence outside the credibility area pertaining to the defendant's or victim's conduct. ${ }^{70}$

\section{E. Social Framework Evidence Relating to Credibility}

One of the most sensitive areas in the law of evidence is the receipt of expert testimony concerning credibility. While the Federal Rules of Evidence do not bar expert testimony on the "ultimate issue" in the case, ${ }^{71}$ the preeminence of the jury in the determination of credibility remains unquestioned. The meaning of the often-repeated phrase that the credibility of the witness is within the "exclusive province" of the jury ${ }^{72}$ is the key question when determining the admissibility of expert testimony relating directly or indirectly to credibility. While this catch phrase provides unfortunately little concrete guidance in resolving the admissibility issue, particular judicial sensitivity in this area is a reality that must be confronted. ${ }^{73}$

70. See FED. R. Evid. 404, 405, 608 .

For a general discussion of these issues, see M. Graham, Handbook of Federal Evidence $\S \S 404.1-404.5,405.1-405.2,608.1-608.5$ (2d ed. 1986).

71. "[T]estimony in the form of an opinion or inference otherwise admissible is not objectionable because it embraces an ultimate issue to be decided by the trier of fact." FED. R. EvID. 704.

72. State v. Black, 109 Wash. 2d 336, 348, 745 P.2d 12, 19 (1987) (en banc). See also, e.g., Head v. State, 519 N.E.2d 151, 153 (Ind. 1988). In Henson v. State, 535 N.E.2d 1189,1192 (Ind. 1989), the Indiana Supreme Court attempted ineptly to explain the result in Head, initially stated in terms of invading the province of the jury, on the basis that such testimony was inadmissible because it was "an area well within a juror's common knowledge and experience." As discussed below, see infra note 81 and accompanying text, while the results are consistent, explanations like that in Henson are both unsatisfying and theoretically unsustainable.

73. For example, the Pennsylvania Supreme Court has taken a broad position against receiving framework testimony in either child sexual abuse or adult rape cases. In almost any form, the court views framework testimony as encroaching upon the jury's exclusive role in determining witness credibility.

In Commonwealth v. Seese, $512 \mathrm{~Pa} .439,517$ A.2d 920 (1986), the court rejected expert testimony that young children as a group do not fabricate stories about sexual abuse. Id. at $441-44$, 517 A.2d at 921-22. It found such testimony to encroach upon the jury's exclusive province in determining credibility matters and to invite the jury to ". "abdicate its responsibility to ascertain the facts relying upon the questionable premise that the expert is in a better position to make such a judgment." "Id. at 443-44, 517 A.2d at 922 (quoting Commonwealth v. O'Searo, 466 Pa. 224, 229, 352 A.2d 30, 32 (1976)).

The court reaffirmed and amplified its position two years later in Commonwealth v. Davis, $518 \mathrm{~Pa}$. 77,541 A.2d 315 (1988). There the expert testified at trial that children who have been involved in sexual experiences typically do not fantasize about them. The testimony given by the expert was free of many of the problems that lead courts in other states to exclude such testimony. See infra notes 127-29 and accompanying text. The expert had not examined the alleged victim and accordingly gave no clinical testimony. Also, his testimony omitted any reference to a statistical basis for his general conclusion. Nevertheless, the Davis court concluded that the testimony was improperly received because it violated the rule set out in Seese that expert testimony impermissibly intruded upon the province of the jury when it amounted to an expert "assessment of the truthfulness of the class of people of which the particular witness is a member." Davis, $518 \mathrm{~Pa}$. at $82,541 \mathrm{~A} .2 \mathrm{~d}$ at 317 . The court made it clear that expert testimony would violate its rule even if the expert made no express comment on the credibility of a witness. It left open, however, the possibility that some testimony by an expert on the general dynamics of child abuse would be proper.

In Commonwealth v. Ferguson, 377 Pa. Super. 246, 546 A.2d 1249 (1988), appeal denied, 557 A.2d 721 (1989), the intermediate court of appeals in Pennsylvania used the rationale of Seese and Davis to hold inadmissible testimony by an expert that the child's behavior and that of child sexual abuse victims were closely allied. Id. at 254-55, $546 \mathrm{~A} .2 \mathrm{~d}$ at 1253. Such testimony does not constitute a 
Indeed, it is because social framework evidence often indirectly (and occasionally directly) involves expert testimony on credibility that it has often been held inadmissible.

Under orthodox common law formulations, the courts faced no serious issue involving the admissibility of expert opinion as to character; it was excluded. The reason was that expert testimony concerning character takes the form of an opinion, and under the strict common law view, character could only be proved by reputation and not by opinion testimony. Expert testimony was received in a related area, however. When an abnormality of the witness affected his or her capacity to perceive or to remember, for instance, expert testimony was generally receivable. ${ }^{74}$ Under Rule 405 (a) of the Federal Rules of Evidence, character testimony may now be offered in the form of opinion testimony, thus removing what had been an indirect but effective bar to expert testimony on character. ${ }^{75}$

direct opinion of an expert concerning credibility or even testimony concerning the credibility of a group. Rather, it concerns the correspondence between the behavior of the child and of the framework group going to whether a sexual assault occurred. Yet, despite the apparently lessened threat to the jury's role in assessing credibility that this form of expert testimony posed, it was excluded. See also Commonwealth v. Higby, 384 Pa. Super. 619, 624, 559 A.2d 939, 941 (1989) (similar testimony properly excluded because it "served only to bolster the credibility of the alleged victim"); Commonwealth v. Emge, 381 Pa. Super. 139, 553 A.2d 74 (1988) (testimony that child's behavior was consistent with those of sexually molested children excluded, the court concluding that "behavior testimony equally invades the exclusive province of the fact finder") (emphasis in original). For a further treatment of the impact of the form of the testimony upon admissibility, see infra notes $110-13$ and accompanying text.

Finally, in Commonwealth v. Gallagher, 519 Pa. 291, 547 A.2d 355 (1988), the state supreme court excluded expert testimony concerning the rape trauma syndrome in a case involving the rape of an adult. The expert first described the symptomatology of the syndrome and the expert's examination of the victim. The expert then rendered an opinion that the victim was suffering from rape trauma syndrome and that the syndrome contributed to the victim's failure to identify the defendant two weeks after the crime. Id. at 293, 547 A.2d at 356-57. The court again found the testimony an intrusion upon the jury's exclusive function in determining credibility and excluded it. Id. at 297,542 A.2d at $358-59$.

These cases reject social framework testimony broadly, ignoring distinctions that courts in other states have found important to admissibility. They reject testimony in both child sexual abuse and adult rape cases. They reject testimony going both to credibility and to whether the sexual abuse occurs and exclude it regardless of the fact that no clinical testimony is given concerning the victim, no statistical basis of the framework testimony is utilized, and no explicit opinion concerning credibility is rendered. The great sensitivity shown by some courts to intrusion on jury determination of credibility appears to be clearly at work in these results.

74. See, e.g., State v. Myers, 382 N.W.2d 91, 95 (lowa 1986) (noting that expert testimony concerning organic or mental disorders is admissible to attack the witness' credibility).

75. FED. R. Evid. 405 advisory committee's note. See, e.g., United States v. Hill, 655 F.2d 512, 516-17 (3d Cir. 1981) (expert testimony concerning defendant's susceptibility to entrapment properly admissible under rules governing proof of character), cert. denied, 464 U.S. 1039 (1984); United States v. Staggs, 553 F.2d 1073, 1075-76 (7th Cir. 1977) (opinion of psychologist that defendant was more likely to hurt himself rather than others improperly excluded in prosecution for assault on federal officer).

Indeed, the advisory committee gave as an example the opinion of a psychiatrist as to the trait of honesty. The committee recognized that no effective dividing line exists between mental capacity, which had been traditionally receivable through opinion testimony, and character evidence, which had been excluded. FED. R. Evid. 405 advisory committee's note. 
However, the expansion of character evidence to include expert opinions has been received with great caution by courts. ${ }^{76}$ The traditional form for receiving character evidence concerning credibility may also have an impact on the receipt of direct testimony by an expert concerning the believability of the witness. An opinion that the witness has good character for truthfulness would appear to be admissible under the Rules, but testimony that in the expert's opinion the witness told the truth on a particular occasion, such as in a conversation with the expert about the incident at issue in the trial, may not be. ${ }^{77}$

Frequently, the results reached by the courts in this area, which generally exclude expert testimony relating to credibility, may be explained by straightforward application of the concepts of helpfulness and relevancy, developed above. In many situations where statements by experts have been excluded, the expert had nothing of substantial value related to his or her expertise to offer on the issue of credibility. ${ }^{78}$ Where the expert lacks such special expertise, excluding the testimony is easily understood, but in other situations, the outcomes are not so simple to explain.

For example, some symptoms of rape trauma syndrome may be difficult to fake; others are counterintuitive and would require substantial research and likely willful deception to fabricate. ${ }^{79}$ Nevertheless, one court flatly rejected testimony concerning the witness' credibility where the expert testified to the

76. For further discussion see infra notes $116-37$ and accompanying text.

The drafters of the revised rules of evidence in North Carolina fashioned a rule that continues traditional practice. They added to Federal Rule 405(a) the following sentence: "Expert testimony on character or a trait of character is not admissible as circumstantial evidence of character." N.C. R. Evid. 405(a).

77. Compare United States v. Azure, 801 F.2d 336, 341 (8th Cir. 1986), with State v. Kim, 64 Haw. $598,609 \mathrm{n} .14,645$ P.2d $1330,1339 \mathrm{n} .14$ (1982). The objection is that the expert does not state an opinion on the character of the witnesses but rather gives an opinion concerning his or her truthfulness on a particular occasion, which is not a general trait of character.

78. See, e.g., State v. Aguallo, 318 N.C. 590, 597-99, 350 S.E.2d 76, 81 (1986) (pediatrician improperly permitted to testify that she formed an opinion during the course of the examination that the child victim was believable). In many of the reported cases, such as Aguallo, one wonders why experts, who are often cautious in the exercise of their professional judgment, would be willing to venture opinions in areas fraught with so much uncertainty.

79. Massaro, supra note 3, at 449-50. See also State v. Allewalt, 308 Md. 89, 96-97, 517 A.2d 74l, 744-45 (1986) (psychiatrist testified in response to defense questioning that he was not relying exclusively upon belief in witness' story, citing the correspondence between witness' story and textbook symptoms).

In this process the expert may be applying a special ability in comparing statements of the witness with observed behavior and symptoms. The expert thus, may possess both a special basis and special skill or experience in making an assessment of credibility measurably superior to lay factfinders. $C$. FED. R. Evid. 803(4) (admits hearsay statements made to medical expert when relied upon by expert to reach opinion even where declarant's self-interest in treatment not involved, apparently under theory that expert evaluates trustworthiness of statement in determining whether to rely on it); Mosteller, supra note 45.

When this author was practicing criminal law, I was told by psychiatrists of claims of hallucinations frequently made by incarcerated defendants who were trying to fabricate an insanity defense. The problem from the point of view of the prisoners was that, being unschooled in the scientific literature, they would pick particularly lurid versions which they apparently believed would instantly demonstrate their insanity. However, among those who were demonstrably ill and for whom fabrication was not suspected, hallucinations having the particular content described by the defendants were never observed. The effort at fabrication accordingly ended quickly in failure. 
difficulty of fabricating testimony ${ }^{80}$ and another refused to exclude such testimony only because it had been provoked by defense cross-examination and had not been the subject of proper objection. ${ }^{81}$ In addition to rejecting claimed specific expertise in evaluating credibility, courts are all but unanimous that experts may not render an explicit judgment concerning the credibility of a witness. ${ }^{82}$

When examining the courts' treatment of social framework testimony directly and indirectly affecting witness credibility, one has the clear sense that the courts are enforcing values somewhat distinct from the traditional concerns of accurate factfinding and a precise balancing of probativity and prejudice. Indeed, it appears undeniable that other values are influencing the courts in their insistence that great care be exercised in the admission of evidence in this area.

In his influential article, Trial by Mathematics: Precision and Ritual in the Legal Process, ${ }^{83}$ Professor Tribe describes the typical lawsuit as only partly an objective search for historical truth. He argues that it is also in an important way a ritual of conflict settlement that is partially inconsistent with a relentless search for the truth. ${ }^{84}$ Professor Nesson more recently has made related arguments that attempt to explain a number of legal rules as designed to produce verdicts that are acceptable, in the sense of permitting the public to defer to the judgment of the legal factinders about a past event. Ready

80. State v. Taylor, 663 S.W.2d 235, 237, 240-41 (Mo. 1984) (en banc) (expert testified that witness "would not be capable of feigning the symptoms" observed; opinion as to witness' credibility held improper).

81. State v. Allewalt, 308 Md. 89, 109, 517 A.2d 741, 751 (1986).

82. See e.g., Tingle v. State, 536 So. 2d 202, 205 (Fla. 1988); Head v. State, 519 N.E.2d 151, 153 (Ind. 1988); State v. Taylor, 663 S.W.2d 235, 237, 240-4l (Mo. 1984) (en banc); State v. Aguallo, 318 N.C. 590, 599, 350 S.E.2d 76, 81 (1986); State v. Rimmasch, 775 P.2d 388, 391-93 (Utah 1989). The one exception is State v. Kim, 64 Haw. 598, 609 n.14, 645 P.2d 1330, 1339 n.14 (1982). Professor Berger argues that Kim is in accord with the spirit of the Federal Rules of Evidence and that, in spite of the rather consistent exclusion of expert testimony directly supporting credibility, its reception follows proper modern evidentiary analysis. Berger, United States v. Scop: The Common-Law Approach to an Expert's Opinion about a Witness's Credibility Still Does not Work, 55 BrookLyn L. Rev. 559, 620-21 (1989). She argues that courts should not categorically exclude all expert testimony of this type. Instead, two limitations should be applied. First, such expert testimony may be admitted only after the witness' credibility is attacked. Id. at 612-13. Second, before receiving such testimony, the court must conclude that its probative value in terms of the reliability of the evidence is sufficiently high to counterbalance its potential to be unduly persuasive and uncritically accepted by the jury. Id. at 60407, 615. See also State v. Bachman, 446 N.W.2d 271 (S.D. 1989), which comes very close to embracing Kim's position, although the court in Bachman rested admissibility in part on the basis that the experts did not "testifly] that the girls were absolutely telling the truth." Id. at 275.

In contrast to the issue of whether an expert may give a direct opinion on the credibility of a witness, courts in different jurisdictions take varying positions on many issues involving admission of social framework testimony in child sexual abuse and rape prosecutions. The extent of agreement in this area appears unique.

83. Tribe, supra note 5 .

84. Id. at 1376-77. The argument that empirical data disrupt other goals of the adversarial process, laden as it is with "necessary" ambiguities, is once again powerfully made in Saks, Enhancing and Restraining Accuracy in Adjudication, Law \& Contemp. Probs., Autumn 1988, at 243. 
deference by the public is important, he argues, since the factual judgments reached provide a basis for imposing significant legal sanctions. ${ }^{85}$

The sensitivity of the credibility determination by the lay jury is clearly near the core of this ritual process and among the most sensitive of all its aspects. I suspect that the caution of the courts in admitting such evidence relates in some important ways to their recognition of these additional values. Indeed, it is difficult to explain some sets of results without reference outside a strict truth-seeking model of trials. ${ }^{86}$

\section{III}

\section{The Narrow View of Social Framework Testimony of Professors Walker and Monahan}

Walker and Monahan, in their article Social Frameworks: A New Use of Social Science in $L a w,{ }^{87}$ argue very persuasively that social framework testimony should be available to assist the jury in deciding cases. However, theirs is a relatively limited view of this type of evidence that places the conduct or condition of a relevant individual in the context of a larger social group. Their definition is certainly more limited than the view taken by litigants and courts. Courts frequently admit evidence that plays the same role as social framework evidence as defined by Walker and Monahan but varies in form from their definition. Their definition also eliminates many of the most difficult issues concerning the use of social framework evidence. Indeed, insofar as evidentiary analysis is concerned, it is the precise manner in which

85. Nesson, The Evidence or the Event? On Judicial Proof and the Acceptability of Verdicts, 98 HARV. L. Rev. 1357 (1985). See also Brilmayer, Wobble, or the Death of Error, 59 S. CAL. L. REv. 363, 376.78 (1986) (describing "process values" that tend to convert whatever result is reached by the litigation process into a definitionally correct result regardless of its theoretical accuracy). But see Shaviro, Statistical-Probability Evidence and the Appearance of Justice, 103 HARv. L. REv. 530, 548-51, 554 (1989) (questioning whether the goal of public perception of justice should or will support limiting the use of statistical proof).

In his concurring opinion to a judgment excluding lie detector evidence by stipulation of the parties, Justice Linde gave a related but broader description of the role of the jury in determining credibility.

The institution of the trial, above all, assumes the importance of human judgment in assessing the statements of disputing parties and other witnesses. The cherished courtroom drama of confrontation, oral testimony and cross-examination is designed to let a jury pass judgment on their truthfulness and on the accuracy of their testimony. The central myth of the trial is that truth can be discovered in no better way, though it has long been argued that the drama really serves symbolic values more important than reliable factfinding.

State v. Lyon, 304 Or. 221, 238, 744 P.2d 231, 240 (1987) (Linde, J., concurring).

86. In this regard, I have in mind expert determinations of credibility that are labeled not helpful to the jury. If the meaning were limited to whether the expert is better able to assess the truthfulness of the witness, I contend that the testimony would be helpful. I suspect that what others have labeled "acceptability" or "process values" or "ritual" plays an important role here.

Nevertheless, one should be cautious in accepting such values unrelated to truthfinding. Such acceptance poses at least an indirect threat to other basic values we espouse in a democratic society. See Gold, supra note 9, at 405. Departure from the goal of scientific accuracy should be taken only with great caution.

87. Walker \& Monahan, supra note 1. 
the expert presents the social framework testimony that raises the most complicated issues. ${ }^{88}$ Walker and Monahan largely avoid these questions.

They distinguish social framework testimony from "clinical" testimony. Social framework evidence in their view involves research that is largely "off the rack" in the sense that it involves use of preexisting research studies that are typically prepared separately from the litigation itself. ${ }^{89}$ And, critically, such social framework evidence is to be presented in the form of instructions by the judge rather than through the testimony of an expert. ${ }^{90}$ Walker and Monahan believe that the variables that are used to produce the framework are generally in the record or can readily be assessed by the jury without the necessity of expert assistance. Where the characteristics are not so easily established, they would permit expert testimony but confine it to those variables that are either not in the record or not capable of direct assessment by the jurors. The expert's presentation would remain separate from the social framework evidence, which would be provided through jury instruction. ${ }^{91}$

By limiting social framework evidence to general data presented to the jury in the form of instructions, Walker and Monahan remove from the picture the majority of the most challenging evidentiary issues. They contend that the social science research indicates that statistical evidence is not overvalued by the jury. ${ }^{92}$ When such research is presented separately from the expert's testimony and no longer carries the aura that may surround an expert's performance, empirical research may well support this general point. ${ }^{93}$ Their further limitation on the presentation of social framework

88. See generally infra Part IV.

89. The court in People v. Hampton, 746 P.2d 947, $951-52$ (Colo. 1987), approved admission of testimony concerning the rape trauma syndrome under limitations like those suggested by Walker and Monahan, although not presented in the form of jury instructions. See infra discussion at note 184 and accompanying text.

90. Walker \& Monahan, supra note 1, at 592.

A major contribution of the work of Walker and Monahan is to open the debate about the type of evidence social frameworks constitute and the process by which it should be evaluated by the courts. They propose that social framework evidence should be viewed not in the narrow sense of adjudicative facts that are particular to the case but somewhat in the sense of legislative facts that are used by the court in its lawmaking function and are not limited to the individual case. They also argue that courts should evaluate empirical research much as they evaluate precedent. Id. at 583-98. See also Walker \& Monahan, Scientific Methodology as Precedent, supra note 1.

Accordingly, when I refer to their view of social framework evidence as a narrow one, I do not intend to suggest that their approach is a wholly conservative examination of the legal issues involved in admissibility analysis. Theirs are innovative suggestions that raise challenging and difficult issues. Indeed, substantial uncertainty remains as to whether courts are capable of evaluating such research as they evaluate legal precedent and whether it is wise to accord such facts the longevity that is often associated with legal precedent. Cf. People v. Kelly, 17 Cal. 3d 24, 32, 130 Cal. Rptr. 144, 149, 549 P.2d 1240, 1245 (1976) (noting that restraint in admitting scientific evidence under the Frye test is appropriate since the decision of the appellate court to admit such evidence remains binding until the scientific community changes its attitude based upon new evidence).

91. Walker \& Monahan, supra note 1 , at $567 \mathrm{n} .23$

92. Id. at 592 .

93. A companion question that must be answered, however, is whether the instruction format for presentation of this information removes not only the objectionable features of social framework evidence but also its effectiveness for the jury. 
testimony to jury instructions and the separation of such evidence from any case-specific testimony by an expert also helps to limit the problems of potential juror overvaluation of the evidence. ${ }^{94}$

Walker and Monahan follow a consistently conservative tack in another aspect of their argument concerning the introduction of social framework testimony. Perhaps most importantly, they accept the analogy between the use of frameworks based on group characteristics to evaluate the likelihood of particular conduct by an individual and character evidence of an individual to establish that he or she acted in conformity with that character trait. ${ }^{\mathbf{9 5}}$

Character refers to the individual's propensity to act in a certain way, while social framework evidence relates to the behavior of a group having similar characteristics to the individual whose conduct is at issue. In both situations the purpose is to use general knowledge to predict specific conduct in a case. ${ }^{96}$ Walker and Monahan argue that

the policy concern that gave rise to a rule barring the admissibility of evidence of an individual's "characteristic" behavior applies with equal force to the use of information on behavior characteristic of the groups to which he or she belongs: individuals should be accountable for their specific acts and not for their general proclivities. ${ }^{97}$

The above position has implications that restrict the use of social framework evidence. In general, character evidence can be offered in the first instance only by the defense and can be used by the prosecution only in rebuttal. Moreover, character evidence relating to the substantive conduct of an individual is excluded entirely from civil litigation except in the extraordinary case where character is at issue, and character evidence concerning credibility can be used only after a witness' credibility is attacked in a specified way. ${ }^{98}$ The authors apparently accept those restrictions. ${ }^{99}$

In suggesting how their proposal may be implemented, Walker and Monahan make one final point of consequence to the general use of social framework evidence and social science learning generally. They contend that such research results are accessible to the courts and can be properly evaluated and used by them. This position, while certainly not conservative, is very problematic. ${ }^{100}$

94. Walker \& Monahan, supra note 1, at 576 n.52. See also Vidmar, supra note 9, at 308.

95. Walker \& Monahan, supra note 1, at 581.

96. Id.

97. Id.

98. See FED. R. Evid. 404, 405, 608.

99. Walker \& Monahan, supra note 1, at 582.

They note, I contend erroneously, that "[ $t]$ his is the way, in fact, that the case law has gone." Id. at 582 n.76. In child sexual abuse cases, for example, some courts have admitted social framework evidence in contexts where character evidence would clearly be barred. See State v. Oliver, 85 N.C. App. 1, 11, 354 S.E.2d 527, 533, disc. rev. denied, 320 N.C. 174, 358 S.E.2d 64 (1989) (framework testimony used by expert to reach opinion that child was victim of assault where no defense attack would have justified use of character evidence). See infra Part IV.A.1.

100. Walker \& Monahan, supra note 1, at 588-91.

Professor Lempert takes a very different view of the general role of social science research in legal analysis. He contends that frequently the citations to empirical research are used in opinions to justify decisions that would have been the same regardless of whether the research existed. He 
I have undertaken a rather extensive recitation of Walker and Monahan's argument before beginning my analysis of the courts' treatment of social framework evidence in child sexual abuse and rape cases because, to borrow their phrase, their analysis creates something of a framework to use in examining this special type of evidence. Their positions are interesting and thought-provoking although, I contend, unduly restrictive in defining what constitutes social framework evidence. ${ }^{101}$

Certainly, if they intend to capture the forms of evidence that lawyers and courts are using in applying group social behavior to decide the facts of individual cases, they miss much of the richness in the actual world of the law. The result of their argument is to make it easy for a limited form of social framework testimony to be received. At the same time, however, their approach appears to reduce the effectiveness of that evidence, to limit greatly the situations in which it may be offered, and to render irrelevant much of the more sophisticated analysis otherwise necessary for proper admission of this evidence.

\section{IV}

\section{ANalysis of Major Admissibility Issues for Social Framework Evidence in Child Sexual Abuse and in Rape Cases}

When one moves beyond a limited view of the use of social framework testimony and examines the uses that courts have made of variants of such testimony in child sexual abuse and rape cases, the difficulties of application of the legal doctrines governing admissibility become readily apparent. I begin with a number of examples taken from child sexual abuse cases.

\section{A. Admissibility Issues in Child Sexual Abuse Cases}

1. The Determination That the Child Was Sexually Abused Because She Exhibits Symptoms Consistent with the Group of Sexually Abused Children. In child sexual abuse cases, an expert may testify concerning what he or she identifies as the "child sexual abuse syndrome," compare the alleged victim's symptoms with those exhibited by children suffering from the syndrome, and, on the basis of

\footnotetext{
argues that the contributions of social science research to judicial decisions should not be exaggerated and observes that the use of empirical findings by the courts is likely to be far more casual than would be customary in the social sciences. Lempert, supra note 7 , at 176-81. See also Evolving Role, supra note 9, at 72-83 (examining institutional competence of courts to evaluate statistical evidence based on case studies and finding tensions); McCord, supra note 14, at 33-34 n.46, 92 (non-legal, scientific materials are generally used poorly in judicial opinions because materials are not typically found in law libraries and most lawyers have little or no training in researching or evaluating these materials).

101. See supra note 4 and accompanying text. See also Vidmar \& Schuller, supra note 59, at 136-37 (viewing social framework evidence more broadly than Walker and Monahan and seeing no need either for such evidence to be "off the rack" in the sense that the studies relied upon were prepared in advance of, and independent of, the specific litigation, or for the evidence to rest upon a systematically collected and analyzed data base as opposed to clinical insights of the testifying expert).
} 
this clinical examination of the child, reach the conclusion that the child has been sexually abused. ${ }^{102}$ Should such testimony be admissible?

As developed above in connection with the evidentiary concepts of helpfulness and relevance, three major issues with empirical underpinnings should govern admissibility. ${ }^{103}$ The first key issue is whether jurors have prejudices concerning child abuse that require correction. Some research suggests that the general populace is well informed about many aspects of child sexual abuse. ${ }^{104}$ However, courts rather consistently have taken a different view. ${ }^{105}$ In order to determine admissibility, one would want to know both the actual gap between social reality and community belief and the level of misperception required before social framework testimony should be presented. However, these questions are not easily answered. ${ }^{106}$

102. The testimony by the expert may be given in several different forms. I have suggested above that the form of the testimony presents the greatest problems for admissibility. See supra note 59 and accompanying text.

The expert need not affix the label "syndrome" to the set of behaviors exhibited by the group that provides the social framework evidence. Likewise, the expert need not draw an explicit conclusion concerning the individual's behavior in the case but instead may provide the data concerning the group and permit the jury to make its conclusions, much as Monahan and Walker suggest could be done through a jury instruction. Finally, the expert may make no explicit comparisons to a group but instead may render an opinion concerning the conduct of the individual in the case based on the expert's general clinical experiences. McCord, supra note 6, at 9. Some of these alternative forms of testimony present the dangers involved in the use of statistical evidence; others do not.

As should be obvious, the issues differ dramatically depending on the precise character of the evidence offered.

103. The relative ignorance of prospective jurors of the social phenomenon is a major issue under helpfulness analysis. See supra notes $37-38$ and accompanying text: The reliability of the social framework evidence and the potential of the evidence to produce prejudice are important issues under relevance analysis. See supra note, 64 and accompanying text.

104. McCord, supra note 6, at 35 (While "there has been very little research on this topic, ... the one study that has been done concluded that for the most part, the potential jury pool is surprisingly well-informed about the topic of child sexual abuse.").

105. See, e.g., State v. Kim, 64 Haw. 598, 607, 645 P.2d 1330, 1337-38 (1982) (common experience of jurors provides "a less than adequate foundation for assessing the credibility of [the] witness," a child sexual abuse victim "whose claims were substantially uncorroborated"); State v. Myers, 359 N.W.2d 604,610 (Minn. 1984) ("The nature . . of sexual abuse of children places lay jurors at a disadvantage."). Cf. State v. Oliver, 85 N.C. App. 1, 11, 354 S.E.2d 527, 533, disc. rev. denied, 320 N.C. 174,358 S.E.2d 64 (1987) ("The nature of the sexual abuse of children, particularly mentally retarded children, places lay jurors at a disadvantage.").

As set out in the preceding note, Professor McCord recognizes that relatively little empirical research has been done on public understanding of child sexual abuse but that the one siudy that has been done revealed a "surprisingly well-informed" public. Nevertheless, Professor McCord argues that "[c]ommon sense dictates" that expert opinion would assist jurors because "[t]o most people the topic of child sexual abuse is unfamiliar and mysterious." McCord, supra note 6, at 34. See also id. at 44-45. Interestingly, rather than his reference to empirical research, it is his general statement, unsupported by empirical data and based only on his "common sense," that has been cited as supporting the admission of credibility evidence in child sexual abuse cases. State v. Castro, 69 Haw. 633, 644, 756 P.2d 1033, 1044 (1988).

106. In the area of child sexual abuse, determining social reality is practically and conceptually difficult. One frequent writer in the area asserts flatly that, "[a]s most mental health professionals who are involved in evaluating and treating child sexual abuse in families indicate, there is no known reliable psychological or physiological test or method for determining whether a person has been abused ...." Bulkley, Legal Proceedings, Reforms, and Emerging Issues in Child Sexual Abuse Cases, 6 Behavioral Sci. \& L. 153, 179 (1988). But see Myers et al., supra note 6, at 52-62, 77 (arguing that the status of social science knowledge has improved recently and that currently experts know a 
The second critical determinant of admissibility is the reliability of an expert's determination from social framework data that a child was the victim of sexual abuse. ${ }^{107}$ The reliability of such determinations remains unclear. Indeed, some authors argue that the determination may not be reliably made by experts in the field. ${ }^{108}$

Third, what, if any, characteristics about the testimony make it likely or unlikely to be overvalued? Expert testimony on this issue typically comes with no bells and whistles in the sense of the trappings of mechanical scientific accuracy. It appears in familiar terms, but it does specifically relate to the witness in the case and may well be more powerful than testimony about a general group not connected by the force of the expert's direct testimony to the conduct or condition of a specific individual. ${ }^{109}$

substantial amount about the reactions of children to child abuse and can thus determine in many cases that abuse occurred). For a discussion of recent research in the area of rape, see infra note 174 and accompanying text.

107. For a general criticism of the ability of experts to diagnose sexual abuse in the mine run case based upon framework evidence, see Note, The Unreliability of Expert Testimony on the Typical Characteristics of Sexual Abuse Victims, 74 GEo. L.J. 429, 449-50 (1985) (authored by Andrew Cohen); see also State v. York, 564 A.2d 389 (Me. 1989) (despite expert testimony that there are professionally recognized characteristics of sexual abuse in children, court ruled such evidence inadmissible as lacking proven scientific reliability); Comment, Syndrome Testimony in Child Abuse Prosecutions; The Wave of the Future?, 8 ST. Louis U. Pub. L.J. 207, 218-19 (1989) (authored by Karla Ogrodnik Boresi). But see Cling, Rape Trauma Syndrome: Medical Evidence of Non-Consent, 10 Women's RTS. L. REP. 243, 245 (1988) (arguing that "[d]uring the [acute phase], rape trauma syndrome is easy to identify and reliably different from ordinary emotional responses of women who were not recently raped").

The cases that admit testimony of the expert about the event of sexual abuse frequently begin with the accepted position that experts can give an opinion that a sexual assault occurred based upon physical evidence. See e.g., State v. Moran, 151 Ariz. 378, 383 n.4, 728 P.2d 248, 253 n.4 (1986); State v. Saldana, 324 N.W.2d 227, 231 \& n.6 (Minn. 1982). They then apply that same reasoning to conclusions based upon psychological evaluations. See Bailey v. State, 89 N.C. App. 212, 219,365 S.E.2d 651, 655-56 (1988); $c$. Massaro, supra note 3, at 440 (drawing the analogy between physical bruises and psychological bruises left in the form of the "rape trauma" syndrome); but see State v. Moran, 151 Ariz. 378, 384 n.6, 728 P.2d 248, 254 n.6 (1986) (distinguishing conclusions based on psychological evaluations from those based on "observable physical facts").

Whether the extension from physical to psychological diagnosis is appropriate rests primarily upon a judgment as to whether psychological testimony is like medical testimony in its reliability or is significantly different. See Bulkley, supra note 106, at 176 (arguing that psychological theories, unlike most medical decisions, are not based on empirically verified foundations, and, accordingly, psychological experts should not be given the license that medical experts are given to testify that sexual contact caused a condition). While some indicators do exist that help psychiatric experts distinguish true allegations of sexual abuse from those that are false, those factors appear,to be far from infallible. Green, True and False Allegations of Sexual Abuse in Child Custody Disputes, 4 J. AM. Academy Child Psychiatry 449 (1986) (suggesting some of the circumstances under which false claims of sexual abuse will be made and ways to distinguish between true and false claims); Terr, The Child Psychiatrist and the Child Witness: Traveling Companions by Necessity, if Not by Design, $4 \mathrm{~J}$. AM. Academy Child Psychiatry 462 (1986) (same).

108. McCord, supra note 6, at 38. The argument is that the actual events involved in the case can generally only be determined by relying on the statements of the alleged victim when psychological diagnosis is involved. Determination of the events thus rests upon assessing the credibility of the witnesses, which experts are not qualified to do reliably in most situations. See supra note 78 and accompanying text \& supra note 106.

109. In terms of the types of factors that commentators such as Professor Imwinkelried might suggest, see Imwinkelried, supra note 60, at 273-74, some aspects of social framework evidence in child sexual abuse cases increase, while others diminish, the likelihood of juror overvaluation of the evidence. The testimony comes with no fancy computer readouts, for example, produced by an apparently sophisticated machine-a fact that should lessen the danger of overvaluation-but often 
Some courts admit such evidence. ${ }^{110}$ On the other hand, other courts have excluded entirely any opinion that the event of abuse occurred, concluding that the testimony lacks scientific validity and may not be received at all."' Another group of courts, while prohibiting direct evidence that abuse occurred, has allowed some framework testimony relevant to the issue to be admitted under various types of limitations. In these intermediate cases, some courts permit the expert to testify regarding attributes of children who are victims of sexual abuse and to identify the relevant characteristics of the child in question. ${ }^{12}$ Others more tightly restrict the testimony, either prohibiting the expert from going beyond a general description of the framework even to make the observation that the characteristics of the framework group and the behavior of the alleged victim are consistent ${ }^{113}$ or imposing more elaborate protections for the purpose of guarding against jury use of the expert evidence to determine that abuse occurred. ${ }^{114}$

the expert relies on an explicit statistical data base, the testimony carries with it the force of the expert's personal bearing and credentials, and the end product is a direct opinion concerning an individual involved in the litigation.

If social framework testimony, even when based upon statistical studies that are explicitly presented to the jury, is to be broadly admissible because it has little potential to be overvalued by the jury, it must be that statistical evidence generally does not overawe the jury. This position, indeed the position of some that statistical evidence is undervalued, see Walker \& Monahan, supra note 1 , at $576 \&$ n.52, may lose whatever validity it has when applied to social framework evidence in which statistics are made more vivid by application to specific individuals in the case. See Vidmar \& Schuller, supra note 59, at 152-53; but see Saks \& Kidd, supra note 5, at 149 (arguing that laymen cannot integrate statistical and anecdotal evidence and therefore tend to ignore the statistical evidence).

110. See, e.g., Glendening v. State, 536 So. 2d 212, 220-21 (Fla. 1988), cert. denied, 109 S. Ct. 3219 (1989); State v. Hester, 114 Idaho 688, 693, 760 P.2d 27, 32 (1988); Townsend v. State, 734 P.2d 705, 708 (Nev, 1987); State v. Bailey, 89 N.C. App.'212, 219, 365 S.E.2d 651, 655-56 (1988).

111. State v. Black, 537 A.2d 1154, 1157 (Me. 1988) (no validation of indicators of sexual abuse relied upon by expert); State v. Maule, 35 Wash. App. 287, 295-96, 667 P.2d 96, 100 (1983) (expert's theory that sexually abused children manifest identifiable characteristics not shown to be scientifically accepted).

One issue on which all courts agree is that the expert may not give an opinion based on the child's testimony that a particular individual committed the offense. Glendening, 536 So. 2d at 221; Hester, 114 Idaho at 695-96, 760 P.2d at 34-35; Townsend, 734 P.2d at 708; State v. Logue, 372 N.W.2d 151, 157 (S.D. 1985).

112. State v. Moran, 151 Ariz. 378, 385, 728 P.2d 248, 255 (1986); People v. Roscoe, 168 Cal. App. 3d 1093, 1099-1100, 215 Cal Rptr. 45, 49-50 (1985); State v. Myers, 359 N.W.2d 604, 609 (Minn. 1984); State v. Middleton, 294 Or. 427, 437-38, 657 P.2d 1215, 1221 (1983); State v. Jensen, 147 Wis. 2d 240, 259, 432 N.W.2d 913, 918-20 (Wis. 1988); but see Commonwealth v. Higby, 384 Pa. Super. 619, 559 A.2d 939 (1989); Commonwealth v. Emge, 381 Pa. Super. 139, 553 A.2d 74 (1988); Commonwealth v. Ferguson, $377 \mathrm{~Pa}$. Super. 246, 546 A.2d 1249 (1988) (discussed supra in note 73).

113. Moran, 151 Ariz. at 385, 728 P.2d at 255; Roscoe, 168 Cal. App. 3d at 1099-1100, 215 Cal Rptr. at 49-50.

114. In a group of fases the California Court of Appeals has developed a somewhat elaborate set of restrictions upon framework testimony of this sort. The court begins with the proposition that under California precedent, framework testimony regarding child sexual abuse may not be used because it is not sufficiently reliable to "predict" that in any particular case sexual abuse occurred. It concludes that, even if the expert testimony provides only the general characteristics of the typical victim of child sexual abuse, the jury may apply such syndrome testimony to the facts of the case and determine that the child was in fact sexually abused in the case at hand. To avoid this danger, the court imposes two principal restrictions. First, the prosecution must identify before any evidence is admitted the specific myth or misconception the evidence is designed to rebut. Second, the court must instruct the jury explicitly that the expert's testimony is not intended and should not be used to determine that the victim's claims of sexual abuse are true. While not imposing it as an explicit 
2. Testimony That the Child Witness Is Truthful. Testimony by an expert that the child is telling the truth can take several forms, just like testimony that tends to establish that the child was the victim of sexual abuse. ${ }^{115}$ First, the expert may testify concerning general characteristics of children that would be supportive of the child's truthfulness, leaving unsaid the explicit opinion that the child is truthful. Alternatively, the expert may testify directly concerning his or her conclusion that the child is telling the truth. This difference in the form of the testimony - whether a recitation of social framework evidence or a direct statement concerning credibility-is generally a critical determinant of admissibility. ${ }^{116}$

a. Framework testimony supporting credibility. The key issues here are the same as those described above with regard to the admissibility of social framework evidence supporting the fact that a sexual assault occurred. First, is there an enhanced danger in child sexual abuse cases of jury skepticism regarding the child's testimony based on general social ignorance of the phenomenon of child abuse? While some courts have stated affirmatively that the answer to this question is "yes," 117 it is unclear that empirical research supports that proposition. 118 Second, how reliable are the data concerning the frequency of false claims of sexual abuse by children? The overwhelming majority of those in the field support the credibility of children who make accusations of sexual abuse, ${ }^{119}$ but this position is again not without its opponents. ${ }^{120}$

restriction on expert testimony, the court also noted that in the typical case framework evidence will not be admissible in the state's case-in-chief because its basic function is to rebut an attack on the victim's credibility. See People v. Leon, 214 Cal. App. 3d 925, 263 Cal. Rptr. 77, 86-87 (1989); People v. Bowker, 203 Cal. App. 3d 385, 391-94, 249 Cal. Rptr. 886, 889-92 (1988); People v. Bothuel, 205 Cal. App. 3d 581, 587-88, 252 Cal. Rptr. 596, 599-600 (1988). See also Note, Child Sexual Abuse Accommodation Syndrome: Curing the Effects of a Misdiagnosis in the Law of Evidence, 25 Tulsa L.J. 143, 167-69 (1989) (authored by Chandra Lorraine Holmes).

115. See supra note 102 .

116. See, e.g., Wheat v. State, 527 A.2d 269, 274-75 (Del. 1987) (expert may testify in general terms concerning characteristics of children relevant to credibility but may not give quantitative figures concerning those characteristics); State v. Oliver, 85 N.C. App. 1, 11, 354 S.E.2d 527, 533, disc. rev. denied, 320 N.C. 174, 358 S.E.2d 64 (1987) (statement concerning the fact that children generally do not fabricate stories about sexual abuse found admissible whereas direct opinion about truthfulness of this child would not have been admitted).

117. See Wheat, 527 A.2d at 273; State v. Castro, 756 P.2d 1033, 1044 (Haw. 1988), discussed infra at notes 153-55; State v. Middleton, 294 Or. 427, 436, 657 P.2d 1215, 1220-21 (1983).

118. On the issue of public perception of the credibility of children, Professor McCord cites conflicting research results on whether jurors are unduly skeptical of the testimony of child witnesses. McCord, supra note 6 , at 46 . He observes that those who support the proposition that juror prejudice exists do so largely on the basis of guesswork and behavioral research that is in an embryonic state. Id. at $5 \mathrm{l}$. Some progress in laying the foundation for producing sound empirical answers is being made with the conclusion that, as eyewitnesses, children "may not fare as poorly with triers of fact as some past research and much folklore would suggest." Leippe \& Romanczyk, Reactions to Child (Versus Adult) Eyewitnesses, 13 Law \& Hum. Behav. 103, 129 (1989).

119. McCord, supra note 6 , at 38 \& n. 210 .

120. See H. Wakefield \& R. Underwager, Accusations of Child Sexual Abuse 301 (1988) ("Our own experience suggests that false accusations of sexual abuse have become more common than is generally believed. As the publicity about child sexual abuse continues, the problem of false accusations is likely to increase."). 
Assuming that the need for the evidence to correct juror misconceptions and the reliability of the framework evidence concerning the infrequency of false claims by children is accepted, in spite of the absence of clear evidence, what is the likelihood of the evidence being overvalued by the jury? Here we have a clash between fundamental, competing positions. Some espouse the view of Professor Tribe that there is grave danger in combining statistical evidence with softer credibility determinations made by the jury on the basis of nonscientific observations because those latter "softer" determinations may be overwhelmed. ${ }^{121}$

Others take a different position about the relative valuation of the two types of data. They contend that the "hard" statistical data are overwhelmed by the "softer" but more vivid anecdotal evidence. ${ }^{122}$ It is not clear, however, that in the credibility area jurors will be presented with vivid anecdotal evidence contrasted with drier, less evocative statistical evidence. Evidence concerning credibility is often indirect and circumstantial. ${ }^{123}$ As a result, the appropriate comparison is likely between "hard," though dry, statistical data and the jurors' inferences regarding witness credibility. These inferences, gleaned indirectly from the witnesses' conduct and their demeanor on the stand, may strike the jurors as no more vivid but less reliable than statistically based evidence.

Finally, the determination being made here-an explicit credibility determination-concerns an area where values external to the goal of accurate determination of the facts may be dominant. Courts have not typically been receptive when presented with an attempt to change fundamentally the method used by jurors to determine credibility. ${ }^{124}$ Judges and lawyers appear sensitive here to the possibility that a relentless effort to determine historical fact accurately through scientific methodology will-open the process to more effective attack. If expert testimony is received, critics of a verdict reached would need only to raise doubt about the accuracy of the initial scientific proof to mount an effective challenge to the jury's result. ${ }^{125}$

With regard to the admissibility of framework evidence regarding witness credibility, courts reach disparate results. They reach these decisions in

121. McCord, supra note 6, at 55-58.

122. See Gold, Federal Rule of Evidence 403: Observations on the Nature of Unfairly Prejudicial Evidence, 58 WAsh. L. REv. 497, 515 (1983).

123. When deciding issues of credibility, jurors must generally rely upon factors such as nuance of body language and inflection and their judgment of whether the witness fared well or badly in responding to cross-examination questions. When discussing these factors in deliberation, it is unlikely that any of those factors is subject to easy description; indeed many jurors may not be able to articulate at all why they have concluded that a witness is credible or incredible. Thus, I suggest, the data on which credibility judgments are typically based should not be categorized generally as vivid anecdotal evidence. Indeed, it may often not be apparent even to the juror who relies upon it.

124. Cf. State v. Taylor, 663 S.W.2d 235, 241 (Mo. 1984) (en banc) ("The history of the exceptionally fine jury system in this state instructs us not to tamper with the jurors' decision process in such manner. . . . As applied here, [testimony concerning rape trauma syndrome] was inimical to the proper jury operation. In spite of the phenomenal and constant accomplishments of science, it does not seem fusty or anachronistic to preserve the integrity of that operation in a confrontation with scientific opinion.").

125. See supra notes $82-85$ and accompanying text. 
apparent response chiefly to differing views concerning the impact of such testimony on the jury. One court has held that an expert may not testify that children almost never lie about sexual abuse, ${ }^{126}$ while another reaches the opposite conclusion and admits such testimony. ${ }^{127}$ Other courts have made admissibility turn on the precise form of the testimony, ${ }^{128}$ holding that it must be general in form-not specifically connected to the child witness ${ }^{129}$ and not quantified regarding the percentage of child witnesses who are dishonest ${ }^{130}$-or requiring at least that the testimony not directly state that the child is telling the truth. ${ }^{131}$

b. Direct expert testimony concerning credibility. Courts are on occasion confronted by testimony from an expert directly giving an opinion that a witness is telling the truth. While such testimony is not social framework testimony as narrowly defined by Walker and Monahan, the opinion represents presumably that expert's comparison of the child's behavior with that of others the expert has seen personally or with the characteristics of a group known to the expert through social framework data. On the basis of some sort of comparison, which may remain unstated and implicit, the expert reaches a conclusion that the witness is telling the truth.

The same variables should determine admissibility as with strictly framework evidence. With regard to the misperceptions of the public, the answer seems to be, as suggested above, that there is no clear evidence of general skepticism by prospective jurors toward the child witness. ${ }^{132}$ Reliability of the testimony presents, apparently, rather substantial problems. While experts may be able to verify the accuracy of sexual abuse charges generally, determination of truthfulness in the individual case severely tests the expertise of most professionals. ${ }^{133}$ With regard to the tendency to overvalue, it is unclear that testimony of this type should be especially powerful. In terms of the standard literature, the expert is using soft

126. State v. Myers, 382 N.W.2d 91, 97 (Iowa 1986). See also Ex parte Hill, 553 So. 2 d 1138 (Ala. 1989) (court rules, inter alia, that it is permissible for expert to testify that children in general do not fabricate reports of sexual abuse).

127. State v. Oliver, 85 N.C. App. 1, 11,354 S.E.2d 527, 533, disc. rev. denied, 320 N.C. 174,358 S.E.2d 64 (1987).

128. Tingle v. State, 536 So. 2d 202, 204-05 (Fla. 1988) (expert may help assess credibility without direct opinion on credibility by explaining whether medical evidence is consistent with child's story and by comparing patterns of child abuse victims' stories with victim's story). See also United States v. Azure, 801 F.2d 336, 340 (8th Cir. 1985).

129. State v. Moran, 151 Ariz. 378, 385, 728 P.2d 248, 255 (1986); State v. Lindsey, 149 Ariz. 472, 475, 720 P.2d 73, 76 (1986).

130. Wheat v. State, 527 A.2d 269, 274-75 (Del. 1987).

131. State v. Bachman, 446 N.W.2d 771 (S.D. 1989) (approving expert opinion evidence that children who stated they had been sexually abused did not suffer from any symptoms of psychosis, delusions, or hallucinations, which court appeared to acknowledge was "opinion testimony that the victims' allegations were truthful," the court justifying admission partially on the basis that the experts did not "testify] that the girls were absolutely telling the truth").

132. See supra note 118.

133. McCord, supra note 6, at 44.

As discussed elsewhere, it would be difficult to maintain that experts never have any greater ability than lay jurors to determine whether the child is testifying truthfully as to the allegations of 
information in an area where the jurors will have some common experience. The jurors should accordingly be able to accord it appropriate weight. ${ }^{134}$

Courts persist, however, in the view that such testimony presents a major problem. ${ }^{135}$ If there is rationality to their position, as opposed to simply a hidebound reactionary opposition to change, it may be based on the mirror image of the problem that commentators such as Professor Tribe contend exists with statistical evidence. The expert has rather soft data, but the jurors have potentially even softer information. ${ }^{136}$ In addition, the form of the expert's testimony permits the expert's personality and credentials to be added to the weight of the opinion. Moreover, relating the evidence to the particular individual adds some concreteness to the testimony that statistically based evidence typically lacks. Finally, the courts appear to have additional concerns relating both to the importance of the issue in the litigation and to values relating to the process of jury trial, discussed above. ${ }^{137}$

\section{Testimony by An Expert Explaining the Innocence of Apparently Unusual Behavior.} While courts are divided on the admissibility of most uses of social framework evidence in child sexual abuse cases, they have been in accord that testimony is admissible by an expert in one class of cases. ${ }^{138}$ When the expert is

sexual abuse. See supra notes 45, 78 and accompanying text. However, the cases where the expert is clearly able to give a reasonably reliable opinion are relatively rare.

The almost unanimous judicial response to exclude the opinion is probably a combination of the relative lack of advantage these experts have over laymen in assessing credibility and the relatively strong tendency of jurors to give full credit to the expert. Also, judicial deference to the special role of the jury in deciding credibility issues-what may be termed "process values"-almost certainly comes into play. See supra notes $82-85$ and accompanying text.

134. See Vidmar \& Schuller, supra note 59.

The expert may, of course, combine an explicit statement of opinion concerning credibility with a direct use of statistical evidence. In that situation, the problems of overvaluing are most substantial.

135. See supra note 81 .

136. See supra text accompanying note 120 .

137. Generally, the limitation on expert testimony regarding credibility rests in part on values separate from the accuracy of factual determinations. When the expert gives a direct opinion regarding the witness' credibility, his testimony threatens the core of those values. Admissibility of such testimony would challenge some central tenets of the institution of the jury.

As a society, we pay dearly in terms of accuracy and speed of adjudication for using a jury system. Were we to lose the finality of its judgment and its special acceptability as a consequence of an effort to bring more scientific accuracy to credibility judgments, the loss would almost certainly outstrip the gain, given the relatively low reliability of expert judgments concerning credibility. $C f$. Tanner v. United States, 483 U.S. 107, 120 (court notes that allowing broad post-verdict inquiry into improper juror behavior would lead to invalidation of some improper verdicts, but such an inquiry would seriously disrupt the finality of the process and "it is not at all clear . . that the jury system could survive such an effort to perfect it").

138. See e.g., State v. Black, 537 A.2d 1154, 1156-57 (Me. 1988) (expert testimony admissible after defense cross-examination to explain timing and sequence of inconsistent statements but such testimony not permitted in prosecution's case-in-chief); State v. Middleton, 294 Or. 427, 657 P.2d 1215 (1983) (expert testimony explaining typical behavior of victim admitted after defense raised issue concerning such conduct); State v. Jensen, 147 Wis. 2d 240, 250-52, 432 N.W.2d 913, 918 (Wis. 1988) (expert's testimony that child's conduct was generally consistent with that of sexually abused children properly admitted to rebut defense suggestion that charge was fabricated to deflect attention from child's misbehavior at school). Cf. Wheat v. State, 527 A.2d 269, $273-74$ (Del. Sup. 1987) (in intrafamily child sexual abuse case, testimony concerning delay in reporting and recantation of allegations of abuse admissible because likely to be seen by lay jurors as inconsistent with truthful accusations and therefore to need alternative explanation); People v. Taylor, 142 
explaining that specific behavior, which the defense has suggested is unusual and demonstrates a lack of credibility, is in fact commonplace among those who have been victimized, the evidence is universally admitted. ${ }^{139}$

One of the major differences between this situation and those discussed above concerns the relative ignorance of the population regarding a relevant social phenomenon. In this situation, there are special reasons that the evidence is needed to dispel a popularly held myth. Presumably the defense made the particular attack on credibility to which the social framework evidence responds because it believed that the jurors would agree that such behavior would be unusual in a truthful person. Moreover, the defense, by virtue of an effective attack, has enhanced whatever misperceptions originally existed.

Reliability of the evidence should be relatively high because the claim of the rebuttal evidence is rather limited. That claim is only that the child's activity is not that unusual, which the framework evidence can readily demonstrate from group behavior. Moreover, the claim of the evidence is not that the behavior being explained itself proves the accuracy of the charges. With regard to the impact on the jury, the testimony may involve some statistical evidence or may rely entirely upon softer, individualized, clinical results. The capacity to overwhelm would appear less substantial in either case than in the situations discussed in the preceding sections. The lessened threat to overwhelm the jury, however, has less to do with the form of the testimony than the limited reach of the testimony. It does not claim to establish that the crime occurred or even that the credibility of the child is excellent. It only explains the proper impact of other evidence, placing a defense attack in context. ${ }^{140}$ Thus, the jury's essential role as determiner of the critical values in the case is left substantially unchallenged.

\section{B. Comparisons Between Admissibility Decisions in Child Sexual Abuse Cases and Those Involving Adult Victims}

State $v$. Kim, ${ }^{141}$ a child sexual abuse case, provides an excellent example of judicial analysis and its reliance on assumptions about the nature of social facts that should be amenable to empirical determination. In Kim, the defendant was charged with having sexual intercourse with his thirteen-yearold stepdaughter. During the course of the cross-examination of the child,

A.D.2d 410, 418, 536 N.Y.S.2d 825, 831 (1988) (testimony explaining why the victim, who knew her alleged assailant, did not immediately identify him was admissible because "the typical reaction of victims of sex crimes is normally beyond the scope of the average juror's knowledge . . ..").

139. Evidence in this category and that discussed supra in Parts IV.A.l and 2, differs not only in that here the defense has mounted an attack on credibility but also that the prosecution is offering only a rejoinder and not affirmative testimony to enhance the credibility of the witness.

140. See supra note 114 for a somewhat elaborate set of restrictions on admission of framework testimony to explain why the child's conduct is not inconsistent with being the victim of sexual abuse. When used indirectly, framework testimony demonstrating that the conduct of the victim is not inconsistent with abuse may be viewed either as supporting the child's credibility, the subject of this note, or as supporting the proposition that abuse occurred, the subject of note 114 .

141. 64 Haw. 598, 645 P.2d 1330 (1982). 
defense counsel asked whether the child had "boyfriends," which the victim ultimately acknowledged, and whether prior to the alleged assault she had felt animosity toward the defendant. ${ }^{142}$ The court ruled that such examination was a sufficient attack on credibility to permit rehabilitation under the rules of evidence. ${ }^{143}$

The prosecution then called a doctor, who was qualified as an expert in pediatrics and child psychiatry. The expert testified that on approximately seventy occasions he had assessed the credibility of children who were allegedly the victims of sexual assault by family members. He compared the behavior of the victim in this case to others he had examined, listed the shared characteristics, and rendered the opinion that he "found her account to be believable."144

The court noted the sensitivity. of expert testimony on credibility since, in a jury trial, " 'the jury is the sole judge of the credibility of the witnesses.' "'145 It repeated the statements of other courts that expert testimony as to witness credibility might constitute " "an invitation to the trier of fact to abdicate its responsibility to ascertain the facts relying upon the questionable premise that the expert is in a better position to make such a judgment" "146 and an " 'invasion of the province of the jury.' "'147

The court rejected any hard and fast rule excluding expert testimony. ${ }^{148}$ It adopted instead a flexible approach that balanced the probative value of the expert testimony against any deleterious effects and excluded as not assisting the jury any evidence failing that balancing process. ${ }^{149}$ Under this balancing approach, the court admitted the testimony.

The court relied upon its perception, unsupported by any explicit citation to empirical evidence, that "the common experience of the jury may represent a less than adequate foundation for assessing the credibility of a witness" where the witness is a child whose complaint is substantially uncorroborated. ${ }^{150}$ It also noted that the expert had provided in his

142. Id. at 600,645 P.2d at 1333 n.3.

143. Id. at 600,645 P.2d at 1333 .

Under traditional evidentiary analysis, credibility may be enhanced only after it has been attacked. While this practice is frequently justified by the argument that the character of the witness is presumed to be good until it is attacked, MCCormick on Evidence, supra note 28, $\$ 49$, at $115 \mathrm{n} .1$, the more accurate explanation is that "[t]he enormous needless consumption of time which a contrary practice would entail justifies the limitation." FED. R. Evid. 608 advisory committee note. Federal Rule of Evidence 608 specifies that "evidence of truthful character is admissible only after the character of the witness for truthfulness has been attacked." FED. R. Evid. 608(a).

144. Kim, 64 Haw. at 600-01,645 P.2d at 1333-34.

145. Id. at 602,645 P.2d at 1334 .

146. Id. at 602, 645 P.2d at 1334 (quoting Commonwealth v. O'Searo, 466 Pa. 224, 229,352 A.2d $30,32(1976))$.

147. Kim, 64 Haw. at 602, 645 P.2d at 1334 (quoting Holliday v. State, 389 So. 2d 679, 680 (Fla. App. 1980)).

148. The court took guidance from the state's newly adopted evidence code modeled on the Federal Rules of Evidence, which, though not effective as to the case at hand, reflected the liberality of the modern trend in evidence analvsis. Id. at 604,645 P.2d at 1335 .

149. Id. at $603-04,645$ P.2d at 1335 .

150. Id. at 607,645 P.2d at 1337-38. 
testimony a substantial basis for his opinion. The court seemed to say this basis demonstrated the basic reliability of his opinion and gave the jury the capability to evaluate independently the quality of that opinion. The court acknowledged that the testimony went to the heart of the jury's function in assessing credibility. ${ }^{151}$ However, it concluded that this fact alone should not bar admissibility given that modern evidentiary analysis no longer excludes evidence because it concerns an "ultimate issue."152

Subsequently, the Hawaii Supreme Court held in State v. Castro ${ }^{153}$ that Kim did not generally authorize admission of expert testimony on the issue of credibility. In Castro, the defendant was charged with the attempted murder of his adult girlfriend. At trial, defense counsel vigorously cross-examined the victim, inquiring into her relationship with the defendant and her sexual preferences. The state, in an effort to rehabilitate the witness, called a psychologist and elicited from him a favorable opinion on the victim's credibility based on his evaluation of her made during an examination after the attack.

The state supreme court ruled this use of expert testimony improper. It distinguished Kim from the later case on the basis that in Kim the common experience of the jury did not provide an adequate foundation for assessing the child witness' testimony. It relied upon a law review article by Professor McCord for the proposition that child sexual abuse is " a particularly mysterious phenomenon .. . seemingly inexplicable to most people' " and " 'unfamiliar and mysterious." "154 By contrast to the circumstances in Kim, the court concluded in Castro that attempted murder was not a particularly inexplicable phenomenon to most people. Under those circumstances, it found the threat that expert testimony would cause the jury to abdicate its responsibility for credibility determination too great to permit admissibility of the expert testimony. ${ }^{155}$

Two cases decided by the Minnesota Supreme Court present a pattern of decisions that rather resembles the one in Kim and Castro and, like it, depends critically upon judgments about the state of juror knowledge and reaction to testimony that should be subject to empirical research. In State $v$. Saldana, ${ }^{156}$ the court examined whether expert testimony was properly admitted when the expert both (1) described the typical post-rape behavior of rape victims and (2) rendered an opinion that the complaining witness was a victim of rape and did not fantasize the rape.

151. Id. at $609,645 \mathrm{P} .2 \mathrm{~d}$ at 1338

152. Id. at 609-10,645 P.2d at 1338-39. See also supra note 71 .

The court dismissed the objection that the testimony was improper as to form under Rule 608(a) in that while going to character it was not phrased in terms of a trait of character but instead was an opinion as to believability on a specific occasion. The court viewed this objection as relating only to phraseology and not to any substantive error. Kim, 64 Haw. at 609 n.14, 645 P.2d at 1339 n.14. But see United States v. Azure, 801 F.2d 336, 341 (8th Cir. 1986); supra note 76 and accompanying text.

153. 69 Haw. 633, 756 P.2d 1033 (1988).

154. Id. at 645,756 P.2d at 1045 (quoting McCord, supra note 6, at $34,44-45$ ).

155. Id. at $644,756 \mathrm{P} .2 \mathrm{~d}$ at $1043-44$.

156. 324 N.W.2d 227 (Minn. 1982). 
The court's admissibility analysis rested on the basic principles that testimony by an expert must be of assistance to the jury and that its probative value must not be substantially outweighed by its prejudicial value. ${ }^{157}$ Using these criteria, the court found both aspects of the expert's testimony inadmissible.

Beginning with the first aspect of the testimony, which may be termed the social framework testimony, the court concluded that the rape trauma syndrome was not reliable as a scientific test to determine whether a rape has occurred. ${ }^{158}$ It asserted that the evaluation of the rape trauma syndrome has not surpassed common sense in its reliability. ${ }^{159}$ The jurors were accordingly just as able to evaluate the testimony as the expert. ${ }^{160}$ The court found dangers from such testimony that required exclusion. It feared that the apparent scientific basis for the testimony would create an aura of special reliability and trustworthiness when the expert testified that the alleged victim exhibited some symptoms of the rape trauma syndrome. ${ }^{161}$

With regard to the expert's testimony that the complaining witness did not fantasize or fabricate her story, the court held the testimony inadmissible because the victim exhibited no special characteristics that would justify admitting testimony relating to her credibility. ${ }^{162}$ Second, the court concluded that the expert had no special ability to determine these issues. ${ }^{163}$ Finally, it observed that the testimony concerned not the witness' general

157. Id. at 229 .

158. Id. at 229-30. See also State v. Black, 109 Wash. 2d 336, 346-47, 745 P.2d 12, 17-18 (1987);

People v. Bledsoe, 36 Cal. 3d 236, 249-250, 681 P.2d 291, 300-01, 203 Cal. Rptr. 450, 459 (1984).

159. Saldana, 324 N.W.2d at 230.

The court gave no support based on empirical research for this position.

160. The court also contended that the evidence was irrelevant in that the issue was what occurred in "this case," not in others. Id. It is hard to take that position entirely at face value, given the general receipt by courts of framework evidence in other areas. In all these situations, the jury makes reference to the facts of the framework cases or studies in deciding what occurred in the case at hand. See supra text accompanying notes 52-53.

161. Saldana, 324 N.W.2d at 230.

As noted above, see infra notes 177.79 and accompanying text, some courts have concluded that the use of a scientific sounding term such as "rape trauma syndrome" itself contributes to a special scientific aura. These courts often focus critically on the terminology of the testimony in determining admissibility.

162. Saldana, 324 N.W.2d at 231-32.

The court appeared to be referring here to a body of legal doctrine that admits testimony concerning the capability of a witness, who for instance is retarded, to tell the truth in contrast to testimony regarding a witness' character or propensity to be truthful, which is generally excluded. Id. at 231. See also supra note 74 . The opinion is unfortunately unclear on this point, and the court instead may have been referring to juror ignorance of the phenomenon of child sexual abuse, which was not involved when the crime concerned the rape of an adult victim.

163. Saldana, 324 N.W.2d at 232.

The court considered that the expert was unqualified to determine both whether the witness could differentiate between reality and fantasy and whether she was telling the truth. Id. It may be that certain experts could conceivably make the first determination. See United States v. Binder, 769 F.2d 595, 604-05 (9th Cir. 1985) (Wallace, J., dissenting) (arguing that experts are permitted to testify to the fact that a witness is capable of telling the truth even if not permitted to testify that witness actually did so). However, apparently the particular expert in Saldana was not so qualified. On the second issue, it is not clear that any expert is able to determine whether a person is lying and certainly in most cases cannot do so reliably. See supra note $\mathbf{7 8}$ and accompanying text; see also supra note 106 . 
tendency to tell the truth but constituted an opinion that she was on this occasion telling the truth, and, as a consequence, the expert's determination of credibility erroneously invaded the "sole province of the jury." 164

In State v. Myers, ${ }^{165}$ the Minnesota Supreme Court reached a different conclusion than it had in Saldana with regard to social framework evidence for child victims of a sexual assault. ${ }^{166}$ It ruled admissible testimony of a clinical psychologist, who had a caseload of sixty intrafamily sexual abuse cases, in which she described characteristics typically observed in sexually abused children and those she had observed in the complaining witness. ${ }^{167}$ The court both acknowledged that an indirect effect of the expert's testimony would be to bolster the child's credibility ${ }^{168}$ and accepted the proposition that the jury might be strongly influenced by expert testimony on this score. However, it asserted that the "nature . . . of the sexual abuse of children places lay jurors at a disadvantage."169 On this basis it distinguished the result in Saldana, where it had concluded that the jurors were as able as the expert to assess the credibility of the alleged victim. ${ }^{170}$

164. Saldana, 324 N.W.2d at 232.

While the court did not mention the general restriction on testimony concerning credibility that requires it to be received in the form of character testimony, the substance of its objection to admission of the testimony here closely tracked that general evidentiary principle. See supra note 77 and accompanying text.

165. 359 N.W.2d 604 (Minn. 1984).

166. In State v. Bachman, 446 N.W.2d 271 (S.D. 1989), the South Dakota Supreme Court approved the distinction drawn by the Minnesota courts in Myers and Saldana between admissibility analysis of framework testimony in cases involving child victims and those involving adults.

167. Myers, 359 N.W.2d at 609 .

While the courts are not uniform in their treatment, this form of the testimony-the expert providing the relevant framework but giving no explicit opinion about the case-permits the admission of the testimony in some jurisdictions. See supra note 114 . But see McCord, supra note 6 , at 58 (arguing that even such framework testimony should be excluded because of its extreme potential to overwhelm the jury).

168. Myers, 359 N.W.2d at 609.

169. Id. at 610 .

The expert also testified that it was extremely rare for children to fabricate claims of sexual abuse, that the child knew the difference between truth and falsity, and that the child was truthful in her allegations. The court ruled that the defendant waived his objections to these aspects of the expert's testimony by the nature of his counsel's cross-examination of the victim's mother. Id. at 609,611-12. However, the court stated that at least the testimony that the child's statements were truthful was otherwise improper since the expert's status might "lend an unwarranted 'stamp of scientific legitimacy' to the allegations." Id. at 611 (quoting People v. Izzo, 90 Mich. App. 727, 730, 282 N.W.2d 10, $11(1979))$.

170. Id. at 610 .

Whether the court was implicitly finding that the social framework evidence is more reliable as to child sexual abuse than it is in the area of rape trauma is unclear. In Saldana, in the rape context, the court found the social framework evidence to be no more reliable than common sense. Perhaps the court in Myers meant to indicate no greater confidence in the reliability of the social framework evidence in the area of child sexual abuse but believed that juror misunderstanding with regard to child sexual abuse meant that the jury would not operate with its typical common sense absent corrective education by expert testimony.

In Wheat v. State, 527 A.2d 269, 274 n.4 (Del. Sup. 1987), the court similarly limited its admission of social framework testimony to child sexual abuse cases. Like Saldana, the Wheat court based the distinction on the lack of reliability of the rape trauma syndrome. Wheal, 527 A.2d at 274 n.4. It also found that in intrafamily sexual abuse cases the complainant's behavior is, "to the average layperson, superficially inconsistent with the occurrence of a rape ... [and] thus requiring an expert's explanation." Id. at 273. Interestingly, in identifying the two areas where juror 
This last point is clearly one where empirical research could provide substantial, indeed critical, enlightenment. Do jurors in fact suffer from more substantial misperceptions concerning the conduct of child victims than that of adult rape victims, or are they generally more skeptical of the former than the latter? ${ }^{171}$ It is hardly obvious that jurors would have great difficulty understanding why, for example, a child would retract a valid allegation of sexual abuse in the face of the prospect that "daddy" would otherwise be jailed. It is equally unclear whether jurors would have more trouble evaluating an explanation of such a retraction than they would have understanding the fact that an adult female who claimed to have been raped by an acquaintance did not flee upon the first opportunity or delayed reporting the crime. Indeed, one might suspect that in the latter case such superficially unusual conduct by an adult, who appeared much like the jurors, would be more difficult to discount without expert explanation than would the apparently erratic conduct of a child. Nevertheless, the court in Myers purported to base its determination on the existence of a social phenomenon-the greater difficulty of jurors in understanding child sexual abuse-without providing any factual support for its position that such difficulty existed at a particularly high level. ${ }^{172}$

\section{Social Framework Testimony in Rape Cases}

In determining the admissibility of social framework evidence in rape prosecutions, courts reach widely varying results. These conflicting decisions occur in spite of the claim that each court is responding to the same basic concerns. Each, in its view, is basing its conclusion on the best available scientific data and is attempting to establish historical events accurately while simultaneously ensuring that the evidence does not distort the trial process or overwhelm the jury.

A number of courts have rejected testimony concerning the rape trauma syndrome. As noted above, the court in State $v$. Saldana, which is somewhat representative of this position, took the view that testimony concerning the rape trauma syndrome had "not reached a level of reliability that surpasses the quality of common sense." 173 This conclusion may implicate questions of whether jurors have general misconceptions about reactions to rape and whether the rape trauma syndrome is reliable in describing and identifying the behavior of victims.

This is an area where research results are particularly pertinent. Professors Frazier and Borgida have completed a study that suggests that

\footnotetext{
misconceptions need correction, the court did not rely directly upon empirical studies. Instead, it cited a mass of decided cases that admitted evidence regarding delays in reporting the offense and recantation by the child of allegations of abuse. Id. at 273-74.

171. See Leippe \& Romanczyk, supra note 118 (suggesting that at least as eyewitnesses, children may not fare so badly vis-a-vis adult witnesses).

172. 359 N.W.2d at 610 .

173. 324 N.W.2d 227, 230 (Minn. 1982).
} 
both of these concerns are met with regard to the rape trauma syndrome. ${ }^{174}$ Many of the courts which have excluded rape trauma syndrome testimony have reached a different conclusion than that suggested by Frazier and Borgida as to the scientific reliability of the evidence. The view of the Saldana court, noted above, that the rape trauma syndrome has not been scientifically established as a reliable factfinding tool to determine if a rape has occurred, ${ }^{175}$ is shared by a number of other courts. ${ }^{176}$

In addition, both courts that consider the evidence of questionable reliability and others that do not, find the scientific aura of the term "rape trauma syndrome" to be very problematic. ${ }^{177}$ For example, in State v. Allewalt, ${ }^{178}$ the Maryland Court of Appeals disapproved use of the terminology "rape trauma syndrome" because the term suggests the syndrome is exclusively associated with rape but approved the use of an

174. Frazier \& Borgida, Juror Common Understanding and the Admissibility of Rape Trauma Syndrome Evidence in Court, 12 LAW \& HuM. BEHAV. 101,105 (1988).

On the issue of common understanding of the public concerning rape, Professors Frazier and Borgida begin by noting that, in contrast to the relatively substantial body of research in the area of eyewitness identification, little has been done concerning common understanding of the after-effects of rape. Id. at 105 . In their study, they administered a questionnaire to experts in the field of the treatment of rape victims and to laymen. Their results showed a high degree of agreement $(84 \%)$ among experts with regard to knowledge about rape and a lower level of accurate information among the control groups, composed of college students $(58 \%)$ and non-academic university employees (57\%). Id. at 112 .

Professors Frazier and Borgida concluded that their results support the admissibility of expert testimony concerning rape. First, the gap between lay knowledge and expert knowledge shows that potential jurors could benefit from expert testimony. Id. at 112,116 . Second, the high degree of agreement among experts about the correct answers to questions concerning rape indicates that "experts believe that rape trauma is distinguishable from prior problems," although there is no indication up to this point that reliability has been demonstrated more directly by experts making independent diagnosis that a particular subject suffered from the rape trauma syndrome. Id. at 117 .

Frazier and Borgida note that, while common knowledge is by no means perfect $(57-58 \%)$ and is less than expert knowledge $(\mathbf{8 4 \%})$, it is far from nil. As a result, they are uncertain whether their research makes the case for expert testimony in the sense of demonstrating necessity for such testimony. Id. at 116 . Their uncertainty about whether their results prove that evidence concerning the syndrome should be admitted is particularly appropriate if there are indeed negative consequences in terms of confusion of issues or overvaluation that may flow from the admission of expert testimony. See also Vidmar \& Schuller, supra note 59, at 155-60.

175. Saldana, 324 N.W.2d at 230.

176. People v. Bledsoe, 36 Cal. 3d 236, 250-51, 681 P.2d 291, 300-01, 203 Cal. Rptr. 450, 45960 (1984); State v. Taylor, 663 S.W.2d 235, 240 (Mo. 1984) (en banc); State v. Black, 109 Wash. 2d 336, 345-48, 745 P.2d 12, $16-18$ (1987); but see New York v. Taylor, 58 U.S.L.W. 2514 (N.Y. Ct. App. Feb. 13, 1990). For discussion of Black, see Note, Expert Testimony on Rape Trauma Syndrome: An Argument for Limited Admissibility-State v. Black, 109 Wash. 2d 336, 745 P.2d 12 (1987), 63 WASH. L. REv. 1063 (1988) (authored by Deborah A. Dwyer) (criticizing result, inter alia, on grounds that the existing scientific research is better than the court believed it to be, and arguing for limited admissibility); Note, "Rape Trauma Syndrome" and Inconsistent Rulings on its Admissibility Around the Nation: Should the Washington Supreme Court Reconsider Its Position in State v. Black?, 24 Willamette L. REv. 1011, 1034 (1988) (authored by Tracy E. Watson) (arguing for limited admissibility if scientific research improves).

177. Bledsoe, 36 Cal. 3d at 251 n.14, 681 P.2d at 301 n.14, 203 Cal. Rptr. at 460 n.14 (1984); Taylor, 663 S.W.2d at 241.

178. 308 Md. 89, 517 A.2d 741 (1986). 
alternative, more neutral label-post-traumatic stress disorder ("PTSD"). 179 Where the scientific aura is completely absent, even the courts that most strongly oppose admissibility of social framework testimony in the form of the rape trauma syndrome admit the evidence. They would allow either lay testimony describing emotional or physical trauma ${ }^{180}$ or expert testimony that the symptoms observed "were consistent with a traumatic experience- even a stressful sexual experience."181

Another group of courts has admitted expert testimony that explicitly refers to the rape trauma syndrome. However, they have attempted in other ways to deal with the perceived problems of the possible overvaluation of the evidence by jurors and the arguable scientific aura of the social framework testimony. In State $v$. McCoy, ${ }^{182}$ the Supreme Court of West Virginia drew what it acknowledged to be a fine line between admissible and inadmissible testimony, holding that the "expert may testify that the alleged victim exhibits behavior consistent with rape trauma syndrome, but the expert may not give an opinion, expressly or implicitly, as to whether or not the alleged victim was raped." 183 In People v. Hampton, ${ }^{184}$ the Colorado Supreme Court imposed somewhat similar limitations. The court approved admission of expert

179. Id. at $108,517 \mathrm{~A} .2 \mathrm{~d}$ at 751 .

The Washington Supreme Court in Black found for the same reasons identified in Allewalt that the danger of prejudice was particularly acute when the terminology "rape trauma" was used but felt that use of PTSD was an inadequate remedy. While the court's reasoning is not entirely clear, apparently it believed the testimony, even in this form, would constitute an unreliable scientific opinion of the defendant's guilt which the court viewed as improperly invading the jury's province. Black, 109 Wash. $2 \mathrm{~d}$ at 349,745 P.2d at 19.

180. Bledsoe, 36 Cal. 3d at 251, 681 P.2d at 301, 203 Cal. Rptr. at 460; Black, 109 Wash. 2d at 349, 745 P.2d at 19. Bledsoe, unlike Black, may permit an expert to testify to the existence of any trauma observed by the expert but would not permit social framework testimony suggesting the scientific significance of that trauma. Bledsoe, 36 Cal. 3d at 251, 681 P.2d at 301, 203 Cal. Rptr. at 460.

181. State v. Taylor, 663 S.W.2d 235, 241 (Mo. 1984) (en banc).

182. 366 S.E.2d 731 (W. Va. 1988).

183. Id. at 737 \& n. 10; see also New York v. Taylor, 58 U.S.L.W. 2514 (N.Y. Ct. App. Feb. 13 1990).

The result in $M c C o y$ appears very consistent with the position taken by the Kansas Supreme Court in State v. McQuillen, 236 Kan. 161, 171, 689 P.2d 822, 829 (1984). In McQuillen, the Kansas court narrowed somewhat a broad endorsement of expert testimony on rape trauma syndrome given earlier in State v. Marks, 231 Kan. 645, 647 P.2d 1292 (1982). The court stated that when consent is the defense to rape "[t]he expert may testify that the patient/victim does possess and exhibit the emotional and psychological trauma consistent with rape trauma syndrome." McQuillen, $236 \mathrm{Kan}$. at 171,689 P.2d at 829. The expert in McQuillen did not testify that the victim was raped or that the stress causing her disorder was intercourse with the defendant, id., and the omission of these points from the testimony appeared important to the court's approval of its admission. See also Simmons v. State, 504 N.E.2d 575, 579 (Ind. 1987) (psychiatric social worker could testify that victim's behavior in giving false version of rape was consistent with rape trauma syndrome).

In Henson v. State, 535 N.E.2d $1189,1191-93$ (Ind. 1989), the Indiana Supreme Court ruled that testimony of this type- testimony concerning the relationship between the victim's behavior and that expected under the rape trauma syndrome-could be used by the defense as well as the prosecution. In Henson, the court held that the defendant's expert had been improperly prohibited from giving the opinion that the behavior of the rape victim in returning to the bar where the rape began was inconsistent with that expected. The supreme court concluded that such testimony was clearly relevant to credibility. In light of its earlier approval in Simmons, 504 N.E.2d 575 (Ind. 1987), of such testimony when offered by the prosecution, exclusion when damaging to the prosecution constituted an abuse of discretion. Id. at 1194 .

184. 746 P.2d 947 (Colo. 1987). 
testimony concerning the rape trauma syndrome to put "in context" the alleged victim's delay in reporting the rape. ${ }^{185}$ Indeed, the testimony made absolutely no direct link between the social framework and the individual. The expert gave social framework testimony in a limited form similar to that suggested by Walker and Monahan. The expert did not testify that the victim suffered from rape trauma syndrome or that she had been the victim of a rape. Indeed, the expert had had no contact with the victim and the testimony concerned only the reactions of rape victims generally, not the particular reaction of the alleged victim. ${ }^{186}$

\section{Conclusion}

In general, I have argued that the admission of social framework evidence should depend principally upon an evaluation of three factors: (1) the relative ignorance of the jury of the social condition involved; (2) the reliability of the social science research as to the social framework involved; and (3) the prejudicial impact of the expert testimony concerning the framework evidence chiefly in terms of its tendency to be overvalued by the jury. This system of analysis unfortunately is not the one that has been applied by the courts. Instead, they have resolved the admissibility issue by focusing most often on one of these issues to the exclusion of the others or by using a mechanical test such as the Frye test, which relates only indirectly to these appropriate factors.

A correct admissibility decision will not be decided by the answer to any one of those three questions but will involve a balance among them. Juror misinformation provides the need for the testimony. The value of the testimony is related to the scientific reliability of the social framework. The harm from the testimony results from the tendency of such testimony to be overvalued. In a perfect world, these factors would be balanced against each other and would be judged against the verdict that would have been reached had no social framework testimony been offered. Finally, the benchmark for admissibility would be whether the jury's decision after exposure to social framework evidence more accurately reflected historical fact than its decision made without having had such exposure.

Unfortunately, while social scientists may be capable of designing a testing methodology sophisticated enough to produce the answers that I suggest are required, limited resources render the development of such a research design extremely unlikely. ${ }^{187}$ Given that reality, what should be the outcome with

185. Id. at 951 .

186. Id.

While not explicitly requiring testimony to follow the form used in Hampton, the court, as in McCoy, see supra note 182 , seemed to rely upon the limited scope of the expert's involvement with the victim in ruling the testimony proper.

187. With regard to determining the "truth" in actual criminal trials, as opposed to simulations, we lack even the theoretical possibility of achieving that result except sporadically since the "truth" is generally not verifiable. When, for example, a defendant confesses after trial or the prosecution unearths dispositive exculpatory evidence, events provide verification of historical fact, but most 
regard to admissibility? One concern that cuts against admissibility is the desire to preserve what I have suggested are additional important values involved in trial by jury. Jury verdicts carry a stamp of finality and authority beyond the mere result of a scientific test. The concern for maintaining such a system appears to be at the core of the general reticence to receive such testimony when it affects an issue of great importance in the case and particularly when it directly affects credibility.

However, broad exclusion of social framework testimony is profoundly conservative and suggestive of an anti-scientific bias. It should therefore not be accepted without suspicion that exclusion reflects only a blind bias or the inertia of the legal system and the traditional, legally trained mind. It must be hoped that through careful research substantial progress can be made on the empirical issues raised in this paper and that, both in terms of the form and the substance of the admissibility analysis and the concrete applications of social science learning in the area of jury behavior, we can make progress in determining when social framework testimony should be introduced to improve the accuracy of results while preserving other critical values involved in the process of trial by jury.

Looking more specifically at judicial decisions in the areas of rape and child sexual abuse, some relatively vague patterns can be discerned. First, social framework testimony is more often received in child sexual abuse cases than in rape cases. The reason is not entirely clear. As articulated in the opinions, it relates to differing judicial assessments of the level of juror common knowledge about the typical reactions of victims of child sexual abuse as opposed to such knowledge about adult rape victims. This distinction between the groups is not based upon documented social science research, however. Instead, the outcome appears to be the product of judicial bias that is more favorable toward child sexual abuse victims, given the current consensus that there exists a terrible social problem in this area, ${ }^{188}$ than toward "alleged" rape victims. ${ }^{189}$ It is certainly hard to find any

often some uncertainty will remain that makes assessing the impact of social framework evidence on the goal of reaching correct jury verdicts largely impossible.

188. While courts are often relatively candid in their result orientation when it comes to dealing with child sexual abuse, few courts have been so open as the Wyoming Supreme Court in Goldade v. State, 674 P.2d 721 (Wyo. 1983), cert. denied, 467 U.S. 1253 (1984). There the court ruled that hearsay statements important to the conviction of the defendant for child abuse were admissible. It acknowledged that

[i]f the goal of our court were simply to pursue the common-law tradition of stare decisis, then the cited authorities must be recognized as supporting the position of the appellant [to exclude the statement]. In this instance, however, the function of the court must be to pursue the transcendent goal of addressing the most pernicious social ailment which afflicts our society, family abuse, and more specifically, child abuse.

Id. at 725 .

189. In the movement to reform rape prosecutions by eliminating evidence of prior sexual history, one of the explicit goals was changing the law so as to take the decision concerning admissibility away from judges, who the reformers believed were themselves subject to biases against rape victims. Galvin, Shielding Rape Victims in the State and Federal Courts: A Proposal for the Second Decade. 70 MinN. L. REv. 763, 791, 873-75 (1986). 
meaningful difference in the reliability of the research pertaining to these two different fields. ${ }^{190}$

Second,-direct statements concerning the credibility of witnesses are almost universally excluded. ${ }^{191}$ Exclusion may largely be reconciled with the scientific knowledge in this area, particularly the lack of support for the general ability of experts to evaluate credibility in a reliable fashion. However, the consensus of results also appears to be strongly influenced by a deeply held feeling that this is an area where science should not intrude.

Third, social framework evidence, in both child sexual abuse and in rape cases, is received most readily when the defendant suggests that the alleged victim's conduct is unusual and that the conduct implies that the allegations are false. Social framework testimony is then received to rebut or rehabilitate. Several explanations for this result appear to be most likely. First, the fact that the defense believed the attack worth making suggests that juror misconceptions likely exist, and the attack exacerbates any misperceptions present. Second, the attack also makes the social framework testimony more relevant by sharpening the conflict on an issue as to which the evidence is most probative. Finally, some element of basic, unanalyzed fairness appears to be operating. The defendant has a right to keep this potentially prejudicial information from the jury, but in order to do so, he must leave issues as to which it is particularly relevant out of the case. ${ }^{192}$

Additional patterns result from judicial efforts to limit the danger that the evidence will be overvalued by jurors or to reduce the aura of science. Fourth, use of special scientific terms, specifically "rape trauma syndrome," is disfavored or prohibited by some courts because of its tendency to suggest a scientific determination that a rape occurred. Fifth, general testimony by laymen or observations of psychological trauma by experts unconnected with any testimony concerning a social framework is preferred to framework testimony. Courts that impose these last two limitations do not dispute the general relevancy of the social framework testimony. They are instead concerned that the aura of science may cause the testimony to have an improper impact upon the jurors that outstrips its probative value when the phenomenon is presented in the form of framework evidence.

Sixth, social framework testimony that the jury can apply to the observed conduct of the alleged victim is preferred to testimony by the expert explicitly concluding that the victim is a member of a framework group. In the area of

190. See supra note 107.

191. The sole judicial dissent occurred in State v. Kim, 64 Haw. 598, 645 P.2d 1330 (1982), discussed supra at notes 141-52, where the court allowed an explicit opinion as to the credibility of a child sexual abuse victim because of its belief that such testimony was needed to correct juror misconceptions.

192. The law has long taken a similar view with regard to the area of character evidence where concerns about prejudice are much like those involved in social framework testimony. The defendant has the right to shield from attack his character relevant to the conduct alleged against him. However, once he uses character evidence to aid his case, the prosecution is permitted to respond in kind. See FED. R. EVID. 404(a)(1), (c) (permitting character evidence concerning the defendant or the victim by the prosecution to rebut defendant's use of similar character evidence). 
credibility, this distinction is decisive. While only one state has admitted an expert opinion explicitly supporting the credibility of a victim, several other states have allowed testimony which accomplishes that result indirectly by setting out relevant information concerning the credibility of victims generally. However, even here the courts require care to be taken regarding the form of the testimony; one state, for example, excluded the use of numerical percentages to support credibility because of the scientific aura of this technique.

The same concerns are discernable in admissibility decisions involving use of the rape trauma syndrome to prove that the victim did not consent to sexual intercourse. Testimony is more likely to be admitted when it omits any direct expert opinion making the connection between the alleged victim and the group of victims exhibiting rape trauma syndrome. As an extreme example, one court cited with approval the fact that all information given by the expert concerned the group, that the expert indeed had had no contact with the alleged victim, and that the testimony could not be construed as expressing an opinion about the particular victim. ${ }^{193}$

Finally, expert testimony that concerns one of the ultimate issues in the case-whether the victim was raped, for example-is excluded in many states while testimony is admitted when it serves only more limited functions, such as corroborating the credibility of the witness once credibility has been attacked. The centrality of the issue to which the testimony relates remains a point of judicial concern, even though the absolute bar to testimony on an ultimate issue has been removed. ${ }^{194}$ The relative balance between probativity and prejudice provides the basis of the decision, with the fear of overvaluation being felt most keenly when the issue is central to the outcome of the litigation.

Looking at these overall results, what can one say concerning their general wisdom? At a gross level, they appear to be reasonable reactions to perceived problems associated with expert scientific testimony concerning social frameworks. They also suggest a cautious approach overall, which is largely appropriate. The courts must perceive tremendous interest among the scientific community in these social phenomena and are probably generally aware that a substantial and growing body of scientific data has been produced. At the same time, social scientists have not been able to agree upon the degree of reliability of these data. Perhaps more importantly, the research effort is in the early stages of understanding how to calibrate precisely the impact of such data upon jurors. Uncertainty as to the impact is a particular concern when one attempts to apply research results to the trials of actual cases where advocates are bent upon maximum use (and indeed

193. See People v. Hampton, 746 P.2d 947 (Colo. 1987), discussed supra at note 184.

194. See FED. R. EvID. 704. 
misuse in some instances) of the scientific testimony. Given these circumstances, a cautious approach is no doubt the wisest course. ${ }^{195}$

When one looks to specific contributions of social science to the adjudicatory process in this area, the impact appears to be relatively limited. As noted above, courts are generally aware of a body of research on social framework evidence, but their opinions betray only a vague understanding of that body of learning. Courts rarely if ever make precise decisions on admissibility based upon the latest scientific knowledge. The results of studies filter into the opinion only occasionally and then probably largely in conformity with results reached independently of the studies.

While not rosy, the prospects for the future hold some promise. During the eighties much progress has been made in understanding and applying framework evidence. Indeed, the vast bulk of caselaw discussed in this article and much of the best research in the area is less than a decade old. However, as I stated in the Introduction, we are not yet close to reaching answers to the very complicated questions that must be resolved if social framework evidence is ever to be rationally and properly admitted. The basic premise undergirding modern evidence law is that broad, wooden impediments to the admissibility of evidence are not appropriate. Courts, as noted above, should be cautious in admitting such evidence given the uncertainty about its reliability and the potential for prejudice. However, there appears to be no reason based upon our current knowledge and experience to create general rules prohibiting admissibility of social framework evidence.

195. Take for example the excellent study by Professors Frazier and Borgida concerning social framework evidence in rape cases. Frazier \& Borgida, supra note 174. It is hard to interpret their results as giving a clear answer concerning the extent to which evidence about the rape trauma syndrome should be received. They found that potential jurors lack full knowledge but have some substantial body of accurate information. When this insight is combined with the research results of Professors Brekke and Borgida the picture is even more murky. They found that social framework testimony has a variable impact on jurors depending upon the form of presentation. Brekke \& Borgida, supra note 59. Considering the studies together, one is left with no clear answer to the question of whether the framework testimony should be generally admissible and, if so, what forms of the evidence should be allowed. 